NBER WORKING PAPER SERIES

\title{
BOOM-BUST CYCLES IN MIDDLE INCOME COUNTRIES: FACTS AND EXPLANATION
}

\author{
Aaron Tornell \\ Frank Westermann \\ Working Paper 9219 \\ http://www.nber.org/papers/w9219 \\ NATIONAL BUREAU OF ECONOMIC RESEARCH \\ 1050 Massachusetts Avenue \\ Cambridge, MA 02138 \\ September 2002
}

The views expressed herein are those of the authors and not necessarily those of the National Bureau of Economic Research.

(C) 2002 by Aaron Tornell and Frank Westermann. All rights reserved. Short sections of text, not to exceed two paragraphs, may be quoted without explicit permission provided that full credit, including $(\mathrm{C}$ notice, is given to the source. 
Boom-Bust Cycles in Middle Income Countries: Facts and Explanation

Aaron Tornell and Frank Westermann

NBER Working Paper No. 9219

September 2002

JEL No. E32, E44, F32, F44

\section{ABSTRACT}

In this paper we characterize empirically the comovements of macro variables typically observed in middle income countries, as well as the 'boom-bust cycle' that has been observed during the last two decades. We find that many countries that have liberalized their financial markets, have witnessed the development of lending booms. Most of the time the boom gradually decelerates. But sometimes the boom ends in twin currency and banking crises, and is followed by a protracted credit crunch that outlives a short-lived recession. We also find that during lending booms there is a real appreciation and the nontradables $(\mathrm{N})$ sector grows faster than the tradables (T) sector. Meanwhile, the opposite is true in the aftermath of crisis. We argue that these comovements are generated by the interaction of two characteristics of financing typical of middle income countries: risky currency mismatch and asymmetric financing opportunities across the $\mathrm{N}$ - and T-sectors.

Aaron Tornell

Department of Economics

UCLA

405 Hilgard Ave, Bunche Hall

Los Angeles, CA 90095

and NBER

tornell@econ.ucla.edu
Frank Westermann

University of Munich and CESifo

Schackstr 4

80539 Munich, Germany

Westermann@cesifo.de 


\section{Introduction}

In recent decades many middle income countries have liberalized their financial markets. Frequently, the post-liberalization period has witnessed the development of lending booms along which credit grows unusually fast. Most of the time the boom has a soft landing, whereby credit growth gradually decelerates. But sometimes the boom ends in twin currency and banking crises, and is followed by a protracted credit crunch. Interestingly, the patterns followed by several macroeconomic variables during the post-liberalization period are common across this set of countries.

In this paper we characterize empirically these common patterns and present a rationalization for them. First, we characterize the evolution of credit following financial liberalizations and the 'boom-bust cycles' that occasionally occur. Second, we show that the comovements of key macroeconomic variables exist more generally, even if we do not condition on the occurrence of crises. As we shall see, these patterns are different, in many respects, from the comovements observed in economies with well developed financial markets, like the US. We will argue that they are generated by two credit market imperfections that are prevalent in middle income countries: an asymmetry of financing opportunities across nontradables and tradables sectors, and systemic bailout guarantees. We will present evidence that supports the existence of these imperfections, and a model that links these imperfections to the facts.

We characterize the boom-bust cycle by means of an event study on the set of middle income countries. ${ }^{1}$ The cycle is centered around twin crises during which a real depreciation coincides with a banking crisis. Prior to twin crises the typical country experiences a real appreciation and a lending boom along which credit grows unusually fast. In the aftermath of twin crises there is typically a short-lived recession and a protracted credit crunch that persists long after aggregate growth has resumed.

The credit crunch hits mainly small and nontradables (N) firms. In fact, N-sector production declines relative to the output of the tradables ( $\mathrm{T}$ ) sector for several years after the crisis, and the credit-to-deposits ratio falls. This asymmetric sectorial pattern is also observed before a crisis as the N-sector grows faster than the T-sector.

In contrast to earlier decades, large fiscal deficits have not taken center stage in the new boom-bust cycles. Furthermore, investment is the component of GDP that experiences by far the largest swings over the cycle, and at the other extreme consumption varies the least.

Panel regressions reveal that the comovements we have described exist in middle income countries even if we do not condition on the occurrence of crises. We find that over the postliberalization period credit growth is positively correlated with the ratio of N-to-T output, with changes in the real exchange rate, and with investment growth. However, credit growth is not significantly correlated with either aggregate GDP growth or consumption.

These comovements and the boom-bust cycle are not observed in counties with developed financial markets like the US. How can we explain them? We argue that they are generated

\footnotetext{
${ }^{1}$ Our sample includes all countries where, in addition to banks, the stock market is a viable source of finance.
} 
by the interaction of two characteristics of financing typical of middle income countries: asymmetric financing opportunities and risky currency mismatch in the balance sheets of banks and firms. While the T-sector has access to several sources of external finance, the N-sector is heavily dependent on bank credit. Banks in turn are strongly exposed to the $\mathrm{N}$-sector and denominate their liabilities mostly in foreign currency. Furthermore, banks' lending is constrained both by their capital and that of the firms they lend to.

How can we explain the simultaneous occurrence of currency mismatch and borrowing constraints in the N-sector? On the one hand, policies that ensure agents against systemic crises (i.e., systemic bailout guarantees), lead agents to take on more risk than they otherwise would. This can explain risky debt denomination. On the other hand, credit market imperfections such as imperfect enforceability of contracts or asymmetric information lead lenders to be very conservative and give rise to credit constraints. The question arises as to whether one can construct an internally consistent framework where guarantees do not neutralize the credit market imperfections. Furthermore, can the interaction between these two distortions generate the dynamic patterns that characterize the boom-bust cycle and the comovements alluded to above? In the second part of the paper we address these issues using the model of Schneider and Tornell (2000).

The first key result is that the interaction of systemic guarantees and enforceability problems generates a self-reinforcing mechanism. On the one hand, if there is sufficient real exchange rate risk: (a) binding credit constraints arise and (b) it is individually optimal for an $\mathrm{N}$-sector agent to issue risky T-debt (i.e., borrow in foreign currency on a short-term and unhedged basis). On the other hand, if many N-sector agents gamble by denominating their debt in $\mathrm{T}$ goods, exchange rate risk may be endogenously created, as the economy becomes vulnerable to self-fulfilling meltdowns of the banking system. If the amount of $\mathrm{T}$ denominated debt is high, a real depreciation can severely squeeze cash flow, or even bankrupt banks altogether. Since they face binding borrowing constraints, they then have to curtail lending to the N-sector. Weak investment demand from the N-sector for its own products in turn validates the real depreciation. The systemic credit risk created by the banking system thus induces endogenous exchange rate risk.

The second key result is that the interaction of binding borrowing constraints and $\mathrm{T}$ denominated debt generates a dynamic path that resembles a boom-bust cycle. During the boom, the real appreciation reduces the debt burden and relaxes credit constraints, permitting unusually fast growth in the bank-dependent N-sector. This leads to further real appreciation, further relaxation of credit constraints and so on. Since the T-sector is not credit constrained, both the credit-to GDP and the N-to-T output ratios can follow increasing paths. However, the existence of risky debt denomination makes the economy vulnerable to self-fulfilling twin crises, during which a real depreciation coincides with both a meltdown of the banking system and a collapse of the N-sector's internal funds. In the aftermath of crisis the N-sector is outperformed by the T-sector. Since banks are strongly exposed to the N-sector, a long-lasting credit crunch outlives a brief recession.

In order to ground the mechanism we have described empirically, we present evidence on the existence of systemic guarantees and on the asymmetry of financing opportunities 
available across sectors. Although many countries have systemic guarantees in place, it is practically impossible to document their existence directly. Systemic guarantees are not limited to promises to hand out a bailout payment to lenders in case of default. More generally, guarantees are implicit in the exchange rate rules and monetary policies a country follows. One could argue that all countries follow policies that aim to avoid systemic crises and therefore have implicit bailout schemes. Since in middle income countries the real exchange rate tends to be a key price, governments tend to follow policies that serve to insure economic actors against real exchange rate risk. Thus, if a critical mass of agents choose not to hedge, the government will do it for them by adjusting policies.

In this paper we investigate whether there are systemic guarantees by looking at the behavior of interest rate spreads. If markets are anticipating a bailout in bad times, expected returns will not be as sensitive to the state of the economy. We find that in most of the countries in our sample, the spreads in non-crisis years are insensitive to the state of the economy suggesting that there are indeed implicit guarantees in those countries.

We document the existence of asymmetric financing opportunities by looking at a panel of nearly 4000 firms surveyed by the World Bank. We find that small firms tend to be mostly in the N-sector, and that obtaining financing is significantly more challenging for firms in the N-sector than for those in the T-sector.

The empirical findings of this paper are related to two economic policy issues: the exchange rate regime and limits on capital flows. With respect to the former, we find that the patterns followed by key macroeconomic variables along the boom-bust cycle are not significantly different in countries with fixed exchange rates than in other countries. This suggests that the mechanisms that generate the boom-bust cycle are not dependent on particular features of specific exchange rate regimes or monetary policy rules.

Financial liberalizations are typically followed by lending booms. As a result, in some policy circles it has been argued that it might be optimal to impose restrictions on capital flows and stop lending booms, as they mainly reflect excessive risk taking and cronism. The evidence presented in this paper points towards a less malignant process. Although twin crises are typically preceded by lending booms, very few lending booms end in crisis. Most of the time lending booms end with 'soft landings' whereby credit gradually decelerates.

The paper is structured as follows. In Section 2 we characterize the boom-bust cycle. In Section 3 we characterize the comovements of macroeconomic variables over the postliberalization period, without conditioning on the occurrence of crises. In Section 4 we present evidence on the existence of systemic guarantees and of the asymmetric financing opportunities across sectors. In Section 5 we present the model. In Section 6 we link the model to the stylized facts. Finally, in Section 7 we present the conclusions.

\section{Stylized Facts}

The experiences of Mexico around the Tequila crisis and of Thailand around the Asian crisis are prototypical examples of a boom-bust cycle. In this paper we will show that several features of such boom-bust cycles are typical of middle income countries that have experienced 
twin crises. Some of the stylized facts that constitute a boom-bust cycle are widely agreed upon, while others have only recently appeared in the literature or have only been associated with particular episodes. ${ }^{2}$ To illustrate these facts we use an event study that includes the set middle income countries where, in addition to banks, the stock market is a viable source of finance (39 countries). ${ }^{3}$ We consider the period between 1980 and 1999 . We start by describing the facts. Then we present the event windows.

\subsection{The Boom-Bust Cycle}

Many recent BoP crises have differed from their predecessors in that currency crises have coincided with banking crises, and the main villains have not been the traditional suspects such as fiscal deficits or current account deficits. This does not mean, however, that the 'new' crises have been totally delinked from fundamentals. Rather:

(i) Twin crises are typically preceded by a real exchange rate appreciation and a lending boom along which bank credit grows unusually fast.

During the lending boom banks fund themselves by borrowing abroad. Furthermore, they typically over-expose themselves to the N-sector and do not hedge the implied real exchange rate risk. Even when banks denominate loans in foreign currency, they face the risk that households and N-sector firms will not be able to repay in the event of a real depreciation. This is because in the event of a real depreciation the debt burden, in terms of domestic currency, will increase significantly.

When the crisis hits, a real depreciation takes place. Since many agents, especially those in nontradables sectors, had denominated their debts in foreign currency during the boom years, the real depreciation has dramatic 'balance sheet effects': many agents see the value of their debt mushroom, while their revenues remain flat. As a result, their ability to service their debts is reduced and their net worth plummets. There is, therefore, a sharp deterioration of the banks' loan portfolio, and the banking system goes under. ${ }^{4}$ To save the banking system bailouts are granted, frequently with IMF support. ${ }^{5}$ Despite this support:

(ii) In the aftermath of a crisis there is a recession, which is typically short-lived.

Furthermore, a protracted credit crunch develops:

\footnotetext{
${ }^{2}$ See Chinn and Kletzer (2000), Demirguc-Kunt et. al. (2000), Eichengreen, et. al. (1995), Frankel and Rose (1996), Gourinchas et. al. (2001), Gupta, Mishra and Sahay (2001), Hutchison and Neuberger (2002), Kaminski and Reinhart (1999), Krueger and Tornell (1999), Sachs, Tornell and Velasco, (1996), and Tornell (1999).

${ }^{3}$ We consider practically all countries with per-capita incomes between $\$ 1,000$ and $\$ 18,000$, plus Sweden and Finland, who have experienced often studied twin crises. The appendix contains the list of the 39 countries we consider.

${ }^{4}$ An alternative explanation for the occurrence of banking crises is that there is a run on banks by depositors. There is no evidence, however, that during the last two decades the problems faced by banks have been initiated by runs (see Demirguc-Kunt et.al. (2000)).

${ }^{5}$ See Jeanne and Zettelmeyer (2001).
} 
(iii) In the aftermath of a crisis credit falls more sharply than GDP, and the gap widens over time even after economic growth has resumed.

The puzzling coexistence of a protracted credit crunch and GDP growth several years after the crisis reflects the fact that aggregate GDP performance masks an asymmetric sectorial pattern:

(iv) In the aftermath of crisis the tradable (T)-sector experiences an acceleration of growth after a mild recession, while the nontradable (N)-sector experiences a sharp fall and a sluggish recuperation. In contrast, prior to a crisis the $N$-sector grows faster than the T-sector.

In the aftermath of crisis it seems as if the economy is doing well and deposit growth has resumed. However, banks do not resume lending. Perhaps because the meltdown that occurs during the crisis leads to poor capitalization of both the banks and the agents they lend to. The asymmetric sectorial response indicates that the agents mainly affected are households, as well as small and $\mathrm{N}$-sector firms. Large and T-sector firms are not very dependent on bank credit, as they have access to other forms of external finance: trade credit, equity markets and bond markets. In contrast, in middle income countries N-sector agents are heavily dependent on bank credit, which is primarily determined by collateral values, not investment opportunities. ${ }^{6}$ A related fact is that:

(v) In the aftermath of crisis there is a sustained increase in the spread between lending and deposit rates.

Facts (iii)-(v) suggest the following transmission mechanism. When the crisis hits, both the interest rate and the spread jump. While large and T-firms are able to shift away from bank credit to other forms of external finance, small and N-firms are not. This results in a deterioration of the banks' credit pool, which in turn feeds back into a higher spread. The outcome is a protracted credit crunch, during which increases in the stock of outstanding bank credit reflect mostly 'evergreening' rather than fresh loans. Along this path the Tsector may initially suffer a mild and short-lived decline, after which it will grow rapidly. The upshot is that the N-to-T output ratio will decline even though aggregate GDP increases.

In order to construct a theoretical explanation it is important to determine which components of GDP drive the typical boom-bust cycle. Is a twin crisis typically preceded by a consumption boom or an investment boom? Is there a big fiscal expansion and/or a current account deterioration before a crisis? In answer to these questions, we find that

(vi) Investment is the component of GDP that exhibits by far the largest (and statistically significant) deviations from tranquil times, while consumption deviations are very mild and insignificant.

\footnotetext{
${ }^{6}$ Firm level evidence on the asymmteric financing opportunities of small and large as well as tradable and nontradable firms has been presented by Gelos and Werner (2002) for the case of Mexico.
} 
To discriminate among models it is also important to know whether crises are self-fulfilling or are generated by a large exogenous shock. It is difficult to determine whether a large exogenous shock was present. We looked to the usual suspects and we find that:

(vii) There is no significant deterioration in either the terms of trade or the US interest rate in the year prior to the crisis.

Stylized facts (i)-(vii) complete our description of a boom-bust cycle. The question we address next is whether the properties of the boom-bust cycle vary across exchange rate regimes. In particular, is it true that only countries with fixed exchange rates experience boom-bust cycles? We find that

(viii) The boom-bust cycle under fixed exchange rates is not significantly different from the cycle under non-fixed regimes. ${ }^{7}$

It is interesting to note that during the 1980s and 1990s the US did not experience the boom-bust cycle we have described. To make this clear Figure 8 depicts the evolution of key macro variables for Mexico and US. It is evident that the US has experienced neither pronounced asymmetrical sectorial patterns nor dramatic swings in the evolution of credit and the real exchange rate. In contrast, the evolution of the economy in Mexico, for example, exhibits a dramatic boom-bust cycle.

\subsection{Lending Booms}

Next, we shift our attention from cycles to lending booms in order to emphasize that although almost every crisis has been preceded by a lending boom, not all lending booms end in crisis. To the contrary: ${ }^{8}$

(ix) The typical lending boom does not end in crisis, but with a 'soft landing.'

Soft landings suggest that not all lending booms reflect either excessive risk taking or cronism. Instead, they may be a symptom of a less malignant process. The fact that bank credit is the only source of external funds for a big set of agents in the economy implies that many agents are not able to exploit all investment opportunities. Instead, their investment is mainly determined by collateral values. In such a world lending booms are episodes during which borrowing constraints are eased.

A related fact is that even during lending booms crises are rare events. In our sample the probability that there is a crisis in a given country-year, conditional on a lending boom, is around $6 \%$.

The question then arises as to what determines the timing of a lending boom. Perhaps these episodes follow structural reforms that improve the long run prospects of a country.

\footnotetext{
${ }^{7}$ This stylized fact is related to the equivalence of equilibria under fixed and floating exchange rates established by Helpman (1981).

${ }^{8}$ This fact has been established by Gourinchas et. al. (2001).
} 
To address this issue we consider the financial liberalization date as a proxy for the timing of such reforms. We find that in our set of countries:

(x) A financial liberalization is typically followed by a lending boom.

The previous two facts suggest that financial liberalization, and the reforms that typically go with it, make the future look brighter than the present. In anticipation, credit constrained agents try to expand capacity to satisfy that increased future demand for their products and services. The implied deficits are frequently financed by foreign capital inflows from abroad, which are channeled to domestic agents through the domestic banking system. Why aren't these flows taking place through the equity or bond markets? Because there are severe enforceability problems, and domestic banks have specific lending skills and collection abilities. Domestic banks, in turn, must issue short term debt in order to be able to get funds (see Diamond and Rajan (2000)). Furthermore, since systemic bailout guarantees are typically present there are incentives for currency mismatch to arise (see Schneider and Tornell (2000)). ${ }^{9}$

Certainly, very large firms and those in the tradables sector can access world capital markets. However, this is not true for the majority of firms operating in the economy.

\subsection{Event Study}

The figures below show the average behavior, across our set of 39 countries, of several macroeconomic variables around twin currency and banking crises during the period 19801999. Index $t$ in the figures refers to the year during which a twin crisis takes place (we say that there is a crisis at $\mathrm{t}$ if both a currency and a banking crises occur during year $t$, or if one occurs at $\mathrm{t}$ and the other at $t+1$ ).

The graphs below are the visual representations of the point estimates and standard errors from regressions in which the respective variable in the graph is the dependent variable, regressed on time dummies preceding and following a crisis. The panel data estimations account for differences in the mean, by allowing for fixed effects, as well as for differences in the variance, by using a GLS estimator. The heavy line represents the average deviation relative to tranquil times. The thin lines represent the $95 \%$ confidence interval. The point estimates corresponding to the event windows in the text are reported in the appendix. ${ }^{10}$

Figure 1 shows that during the year prior to the crisis the typical economy in our set of countries experiences a $5 \%$ appreciation relative to tranquil times, and that this appreciation is statistically significant.

\footnotetext{
${ }^{9}$ Stylized facts (ix) and (x) are related to the findings of Kaminsky and Schmukler (2001), who characterize stock market cycles in a sample of 28 countries. They find that within three years of opening up the financial system, boom-bust cycles become more pronounced. However, over the long run these cycles are smoother in liberalized economies.

${ }^{10}$ The patterns in the event windows we present below are basically the same as the patterns that would arise if we were to consider a subset of countries that have experienced well known crises: Argentina, Brazil, Chile, Indonesia, Finland, Korea, Malaysia, Mexico, Phillippines, Sweden and Thailand. The event windows for this subset of countries is presented in the appendix, Figure B.
} 


\section{Figure 1: Real Appreciation}

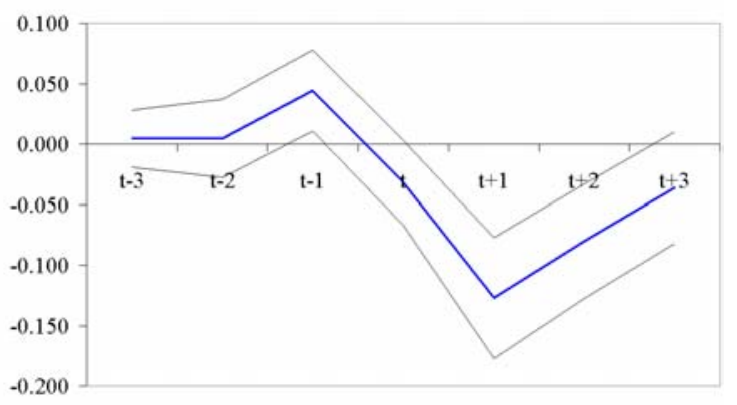

Note: the real exchange rate is proxied by the ratio of PPI/CPI

There exit different views on how to better measure changes in the real exchange rate. Engle (1999) has argued that most of the variance in the real exchange rate is due to variations in the relative price of tradables at home and abroad. While this appears to be case for the high income countries he considers, Betts and Kehoe (2001) find in a study of 52 countries over the period 1980-2000, that variations in the real exchange rate reflect mainly changes in the relative price of nontradables and tradables.

In this paper we take the second view and proxy the real exchange rate by the PPI-to-CPI ratio. A similar pattern emerges when looking at the standard definition of real effective exchange rates, such as in the International Financial Statistics of the IMF.

Figure 2 illustrates the existence of a lending boom in several different ways. Panels (a)(b) refer to the stock of real credit: during the two years prior to the crisis its growth rate ${ }^{11}$ is significantly higher than during tranquil times (around 3\%), and its level is significantly above the Hodrik-Prescott trend. ${ }^{12}$ Panels (c)-(d) show that the same behavior is exhibited by the credit-to-GDP and the credit-to-deposits ratios.

When twin crises hit there is an average real depreciation of around $16 \%$ relative to tranquil times (which is statistically significant). Real credit growth declines back to the growth rates that are observed during tranquil times, after being above the tranquil time mean in $t-1$ and $t-2$. The lending boom thus comes to an end in the year of the crisis. ${ }^{13}$

\footnotetext{
${ }^{11}$ Many papers look at deviations from a Hodrick-Prescott filter rather than growth rates. This has the advantage of having a more flexible trend and a corresponding definition of cycles. However, the HP-filter can be a poor indicator of the trend, if there are structural breaks in the beginning or the end of the period, in particular if the sample is very short. We therefore look at both, growth rates and deviations from the HP-trend.

${ }^{12}$ The deviation of the HP-trend is not exactly equal to zero on average for all countries. Therefore, to be more precise, the graph shows the "deviation from the average deviation from the HP-Trend during tranquil times". However the later is close to zero in most countries.

${ }^{13}$ Two comments are in order. While the growth rates are easily comparable across countries, the levels are not due to different long term trends, structural breaks, etc. (unless they represent the level of a ratio, such as credit/deposits or credit/GDP). The HP-trend is therefore a trend corrected proxy for the levels.
} 
Let us consider now what happens in the aftermath of crisis. As we can see in Figure 3 , both during and the year after the crisis the growth rate of GDP is approximately 5\% below its level during tranquil times (panel a). The growth rate starts recovering at $t+2$ and it attains its tranquil time mean growth rate by $t+3$. Adding the average GDP growth during tranquil times of $2.8 \%$, it follows that the recession lasts only for 2 years ( $\mathrm{t}$ and $\mathrm{t}+1)$. Looking at deviations from an HP-trend tells the same story (panel b).

Figure 2: Bank Credit

a) Real Credit (growth rates)

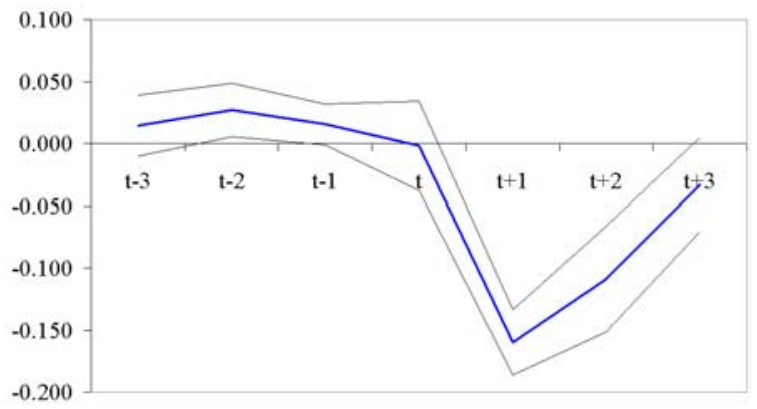

c) Credit/GDP

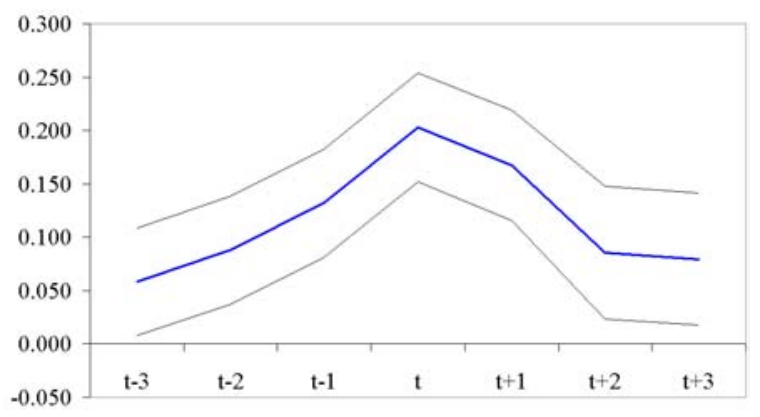

\section{b) Real Credit (deviations from HP-Trend)}

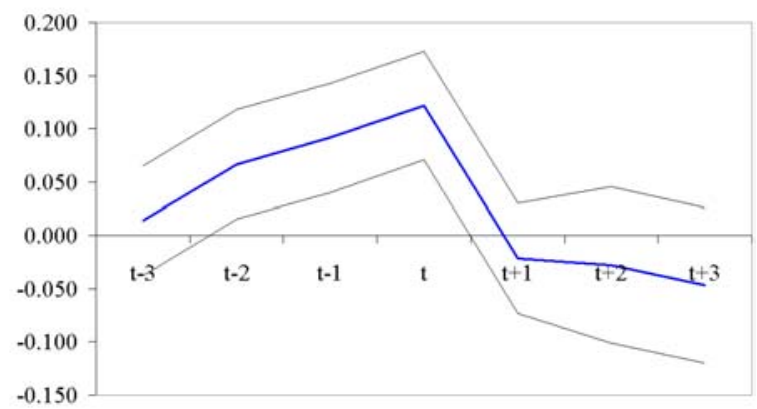

\section{d) Credit/Deposits}

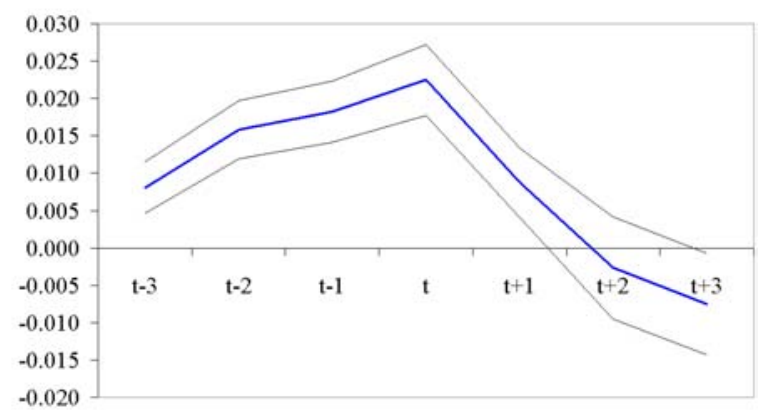

Note: "Credit" is the credit provided by domestic deposit money banks to the non-government -, non financial institution - private Sector. The Hodrick-Prescott trend is constructed with $\lambda=100$. Deposits are the sum of demand deposits and time-, savings- and foreign currency deposits, by domestic deposit money banks.

Figure 2 shows that in the year after the onset of the crisis credit falls more severely than aggregate GDP. The puzzling fact is that the 'credit crunch' becomes more severe through time: the credit-to-deposits and credit-to-GDP ratios decline monotonically. Even by $t+3$ there is no sign of a reversal of the credit crunch. In fact, at $t+3$ the credit-to-deposits

Second, the fact that the HP deviations are positive at $t$ may reflect the 'evergreening effect.' 
ratio becomes significantly lower than its tranquil time's level! Put another away, from the onset of the crisis until $t+3$ GDP experiences a cumulative growth rate loss of $13 \%$, while the cumulative loss in real credit is about 30\%. It is interesting, though, that not all of the financial deepening gains made during the boom are lost during the bust, as suggested by the behavior of the credit-to-GDP ratio.

Figure 3: Aggregate Output

\section{a) Real GDP (growth rates)}

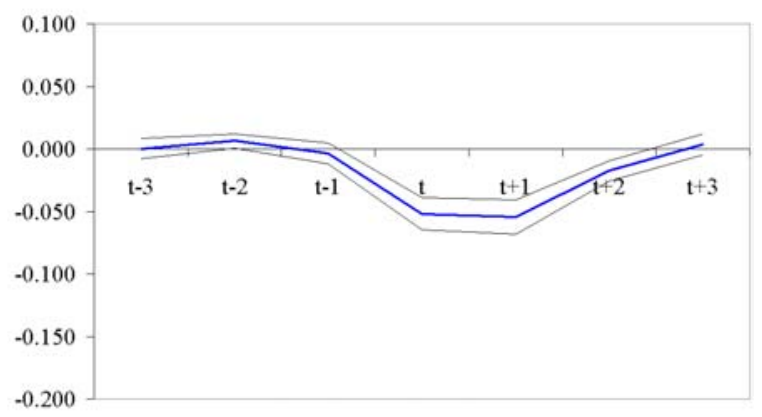

\section{b) Real GDP (deviations from HP-Trend)}

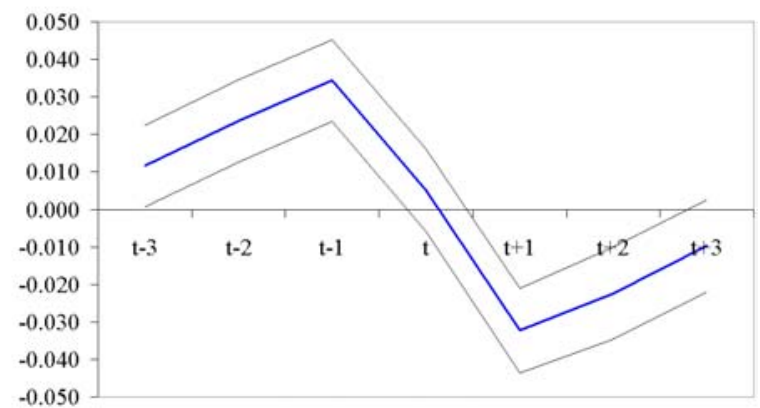

Figure 4 looks at the ratio of nontradables-to-tradables production. As we can see, prior to the crisis the $\mathrm{N} / \mathrm{T}$ ratio is significantly above its tranquil times level, while in the aftermath of the crisis the $\mathrm{N} / \mathrm{T}$ ratio follows a declining path, and it becomes significantly lower than its tranquil times level by $t+3$. Interestingly, this path is quite similar to that followed by the credit-to-deposits ratio in Figure 2.

\section{Figure 4: Non-tradables-to-Tradables Output Ratio}

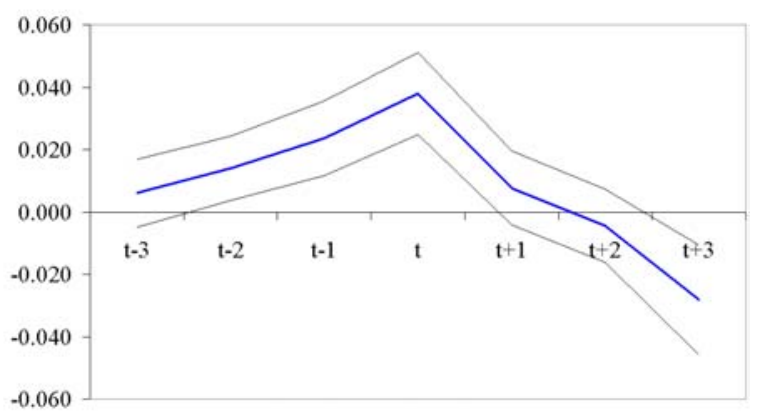

Note: Construction, Services and Manufacturing where classified as $\mathrm{N}$ or $\mathrm{T}$, according to the variance of the sectorial real exchange rate reported in the appendix. In cases where sectoral price data where not available for Construction, Construction was classified as $\mathrm{N}$ by default.

We proxy N-sector and T-sector production with data for construction, manufactures 
and services. Since the price of N-goods tracks international prices less closely than that of T-goods, for each country we classify as $\mathrm{N}(\mathrm{T})$ sector in which the sectorial real exchange rate varies the most(the least). Construction is never classified as a T-sector, while for services and manufacturing the choice between $\mathrm{N}$ and $\mathrm{T}$ varies across countries. ${ }^{1415}$

Figure 5 exhibits the behavior of the spread for a set of 11 countries for which we have good data. ${ }^{16}$ The figure shows that when the crisis hits, there is an upward jump in the spread between lending and deposits rates. Moreover, the spread remains significantly higher 3 years after the onset of the crisis.

\section{Figure 5: Interest Rate Spread}

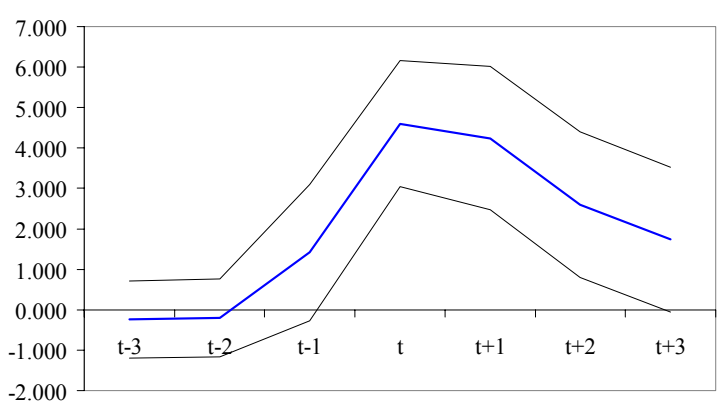

Note: The interest rate spread is the interest rate charged by banks on loans to prime customers minus the interest rate paid by commercial or similar banks for demand, time, or savings deposits.

Figure 6 looks at the behavior of GDP's components relative to tranquil times. Invest-

\footnotetext{
${ }^{14}$ The N-sector is proxied by construction in 17 countries, by services in 22 countries and by manufacturing in 5 countries. The T-sector is manufacturing in 39 cases and services in 5 cases. We consider that the criterion we use captures better the concept we want to measure than the exports-to-production ratio. In any case the results are robust to changes in the definition of non-tradables, as for most countries both indicators coincide.

${ }^{15}$ Evidence on the evolution of the N-to-T output ratio based on firm level data is more difficult to obtain. Most surveys on tradable and non-tradable firms, such as the Word Business Economic Survey (WBES), only have data for one year and do not allow us to trace the time path of output throughout a crisis. An exception is the FACS data set of the World Bank (Firm analysis and competitiveness survey). Hallward-Driemeier (2000) reports that exporters recover better after the crisis than Non-Exporters. Other data sets, such as Worldscope, contain information about tradable and non-tradable firms in the time series dimension, but include only large, stock-listed firms and the patterns become more difficult to interpret in the context of our model. From our perspective, all of these firms would belong to the T-Sector. The Evidence on large, stock listed firms is mixed. Borensztein and Lee (2000) find for Korea, that large chaebol firms do not have easier access to external finance than other stock listed firms. On the other hand they find, that export oriented firms experienced an increase in sales after the crisis. Using the Worldscope database, Forbes (2002) finds that in a set of 42 countries stock listed firms with a higher share of foreign sales exposure have a significantly better performance after depreciations.

${ }^{16}$ Argentina, Brazil, Chile, Indonesia, Finland, Korea, Malaysia, Mexico, Phillippines, Sweden and Thailand.
} 
ment exhibits a significantly higher growth rate of $2-3 \%$ during the three years prior to a crisis and a lower growth rate of $1-2 \%$ during $t+1, t+2$ and $t+3$. For consumption, there is neither an increase before the crisis, nor a decrease after the crisis. Government expenditure is not significantly different, except for the year of the crisis and in $t+2$, when it is significantly higher. Lastly, exports are not significantly different from tranquil times in the build up, but clearly are above in the aftermath of a crisis. This pattern is consistent with our previous observation that the T-sector suffers less after the crisis than the N-sector.

\section{Figure 6: Components of GDP}

\section{a) Investment/GDP}

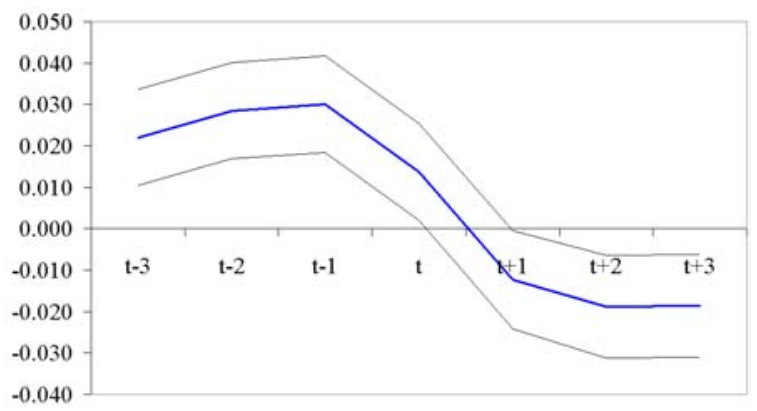

c) Government Expenditure/GDP

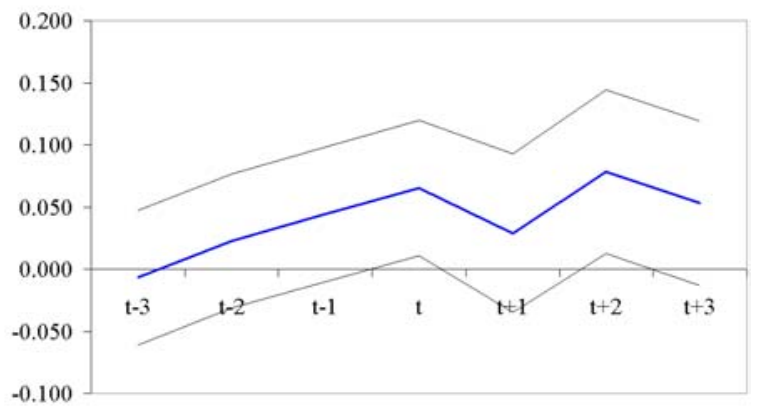

b) Consumption/GDP

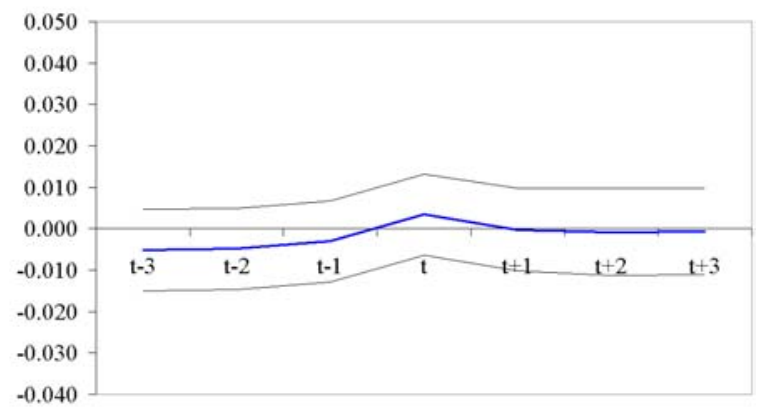

d) Net Exports/GDP

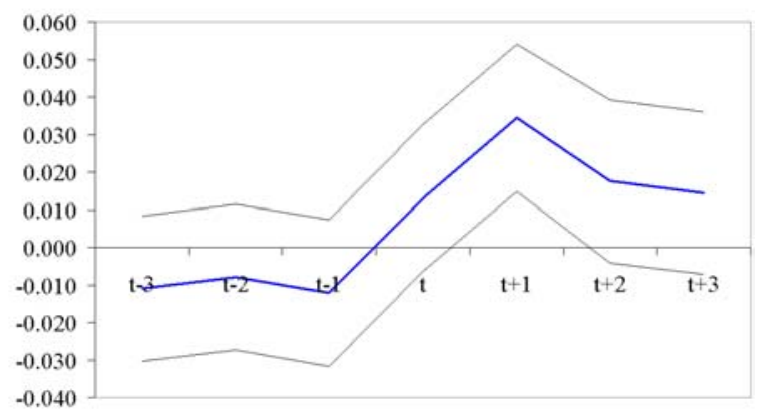

Figure 7 addresses the question of whether crises are caused by 'big exogenous shocks.' It shows that both at $t$ and at $t-1$ the terms of trade and the US interest rate are not significantly different than their tranquil times means. Of course, there might be other exogenous shocks that rock the boat. The point is that neither the terms of trade nor the US interest rate can be invoked to explain the occurrence of crises. Furthermore, to the best of our knowledge, no one has yet identified any exogenous shock as the cause of well known crises, such as the Tequila or Asian crisis. 
Figure 7: External Shocks?

a) Terms of Trade

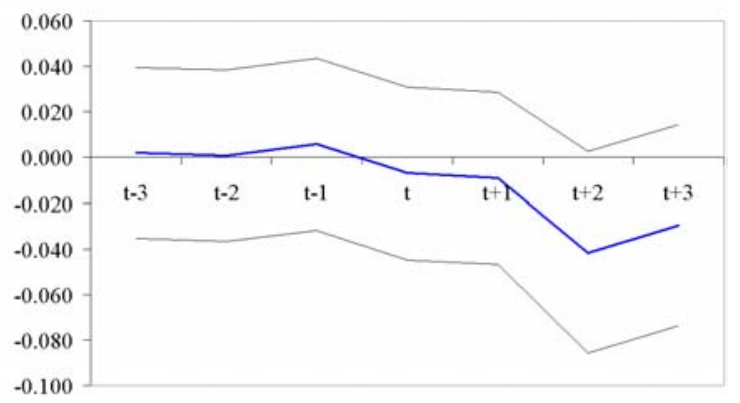

b) US Federal Funds Rate

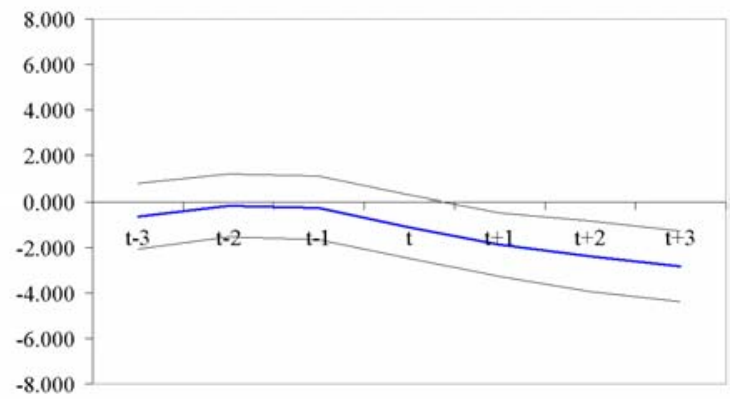

Figure 8 presents the evolution of key variables for Mexico and the US. Here we choose the period 1989 to 1999 for Mexico and 1986 to 1996 for the United States, as the early 1990s are often argued to have been characterized by a credit crunch in the US. We find that the behavior of the main variables around the 1994 crisis in Mexico and the 1991 recession in the US are fundamentally different. In particular, asymmetric sectorial patterns are evident in Mexico, while not in the US. ${ }^{17}$ A common feature is that real GDP recovered quickly in both countries.

\footnotetext{
${ }^{17}$ In these graphs, tradable output in both countries is proxied by manufacturing and non-tradable output is proxied by construction.
} 
Figure 8: Credit, GDP and the N-to-T output ratio in Mexico and the US

Mexico
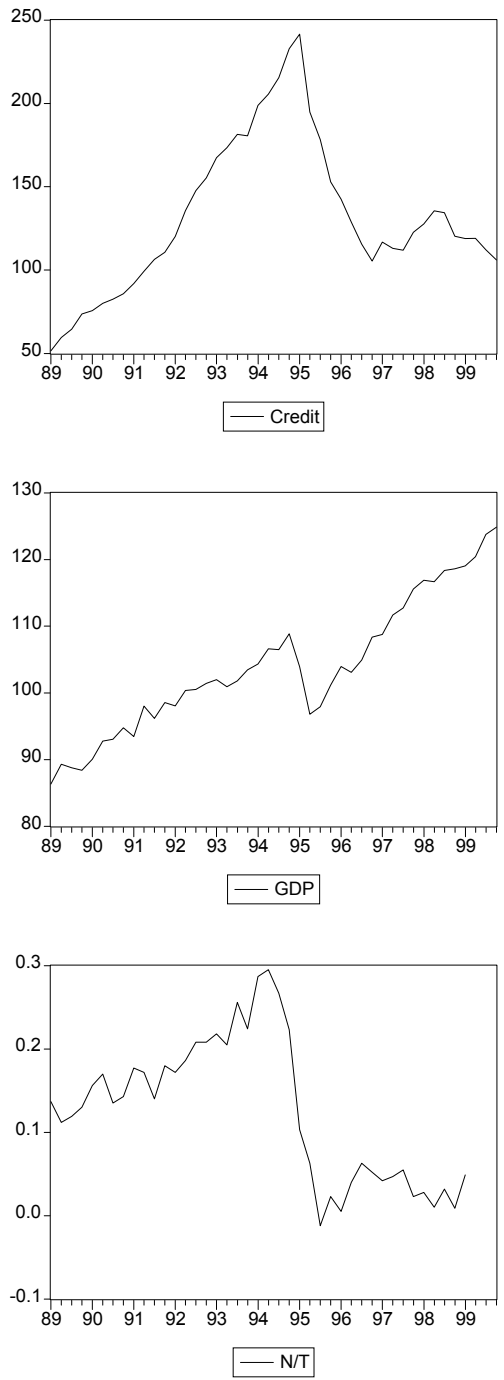

United States
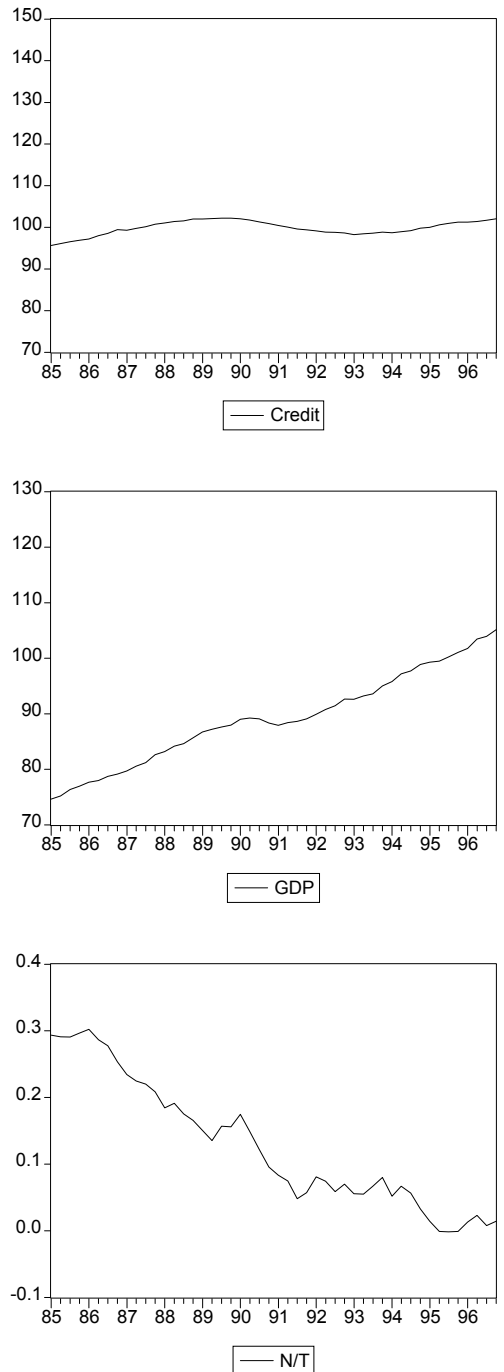

Note: This figure displays the time path of real domestic credit, the real exchange rate and the ratio of nontradable to tradable output, as proxied by Construction and Manufacturing.

In order to investigate whether the boom-bust cycles are dependent on whether the exchange rate regime is fixed, we break our set of countries into two groups: fixed and non-fixed. There are two ways to make this classification: de jure and de facto. Figure 9 shows the event windows corresponding to the de facto classification by Levy-Yeyati and Sturzenegger (2000). ${ }^{18}$ Although there are differences in the details, all of the variables

\footnotetext{
${ }^{18}$ The event windows for the de jure clasification, based on Berger et.al. (2000) are reported in Figure A
} 
display patterns that are broadly similar between the two groups of countries, both before and after the crisis.

in the appendix. The graphs look qualitatively the same as those in Figure 9. In fact, for most countries in our sample de jure and de facto indicators coincide. A notable exception is Mexico 1994, which was fixed de facto, but not fixed de jure. 
Figure 9: The boom bust cycle under fixed and non-fixed exchange rate regimes (de facto classification)

Fixed

Real Appreciation

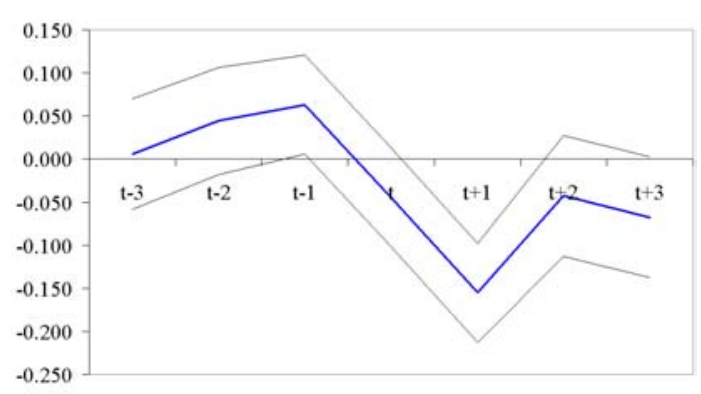

Aggregate Output

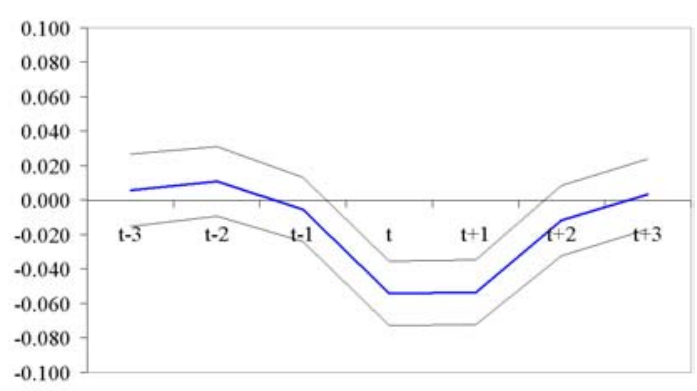

Credit/Deposits

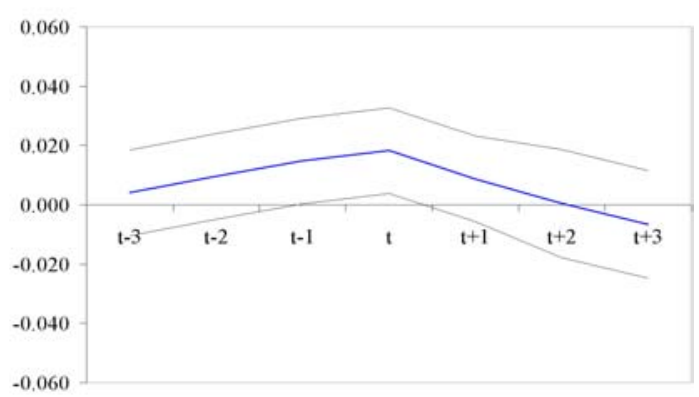

Non-tradables-to-Tradables Output Ratio

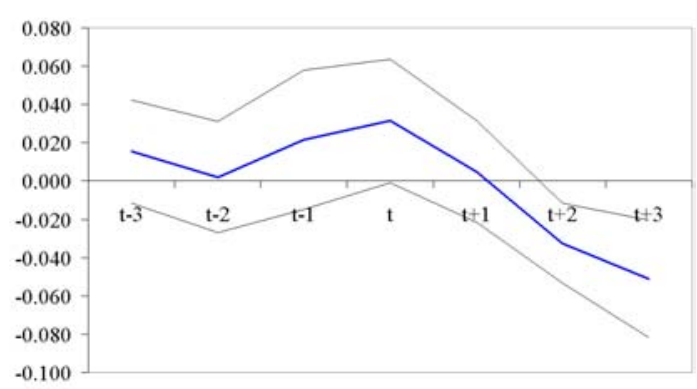

Non-Fixed
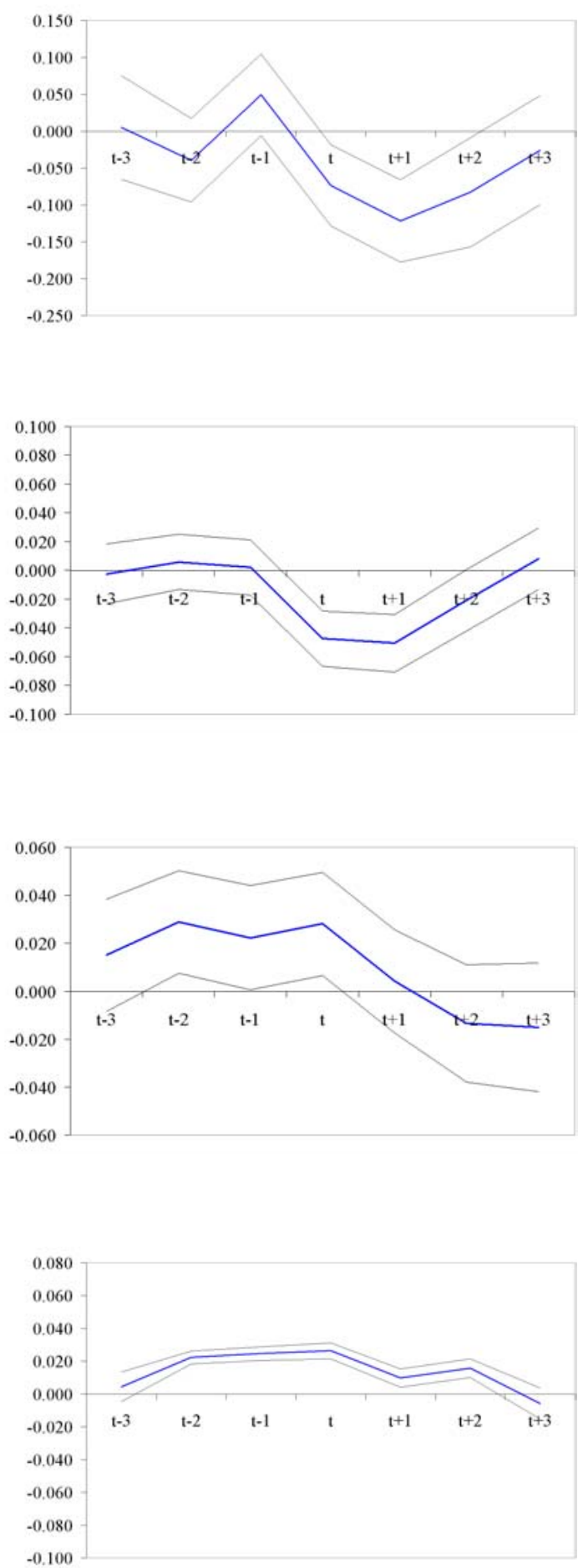


\section{Figure 9: Continued}

Investment/GDP
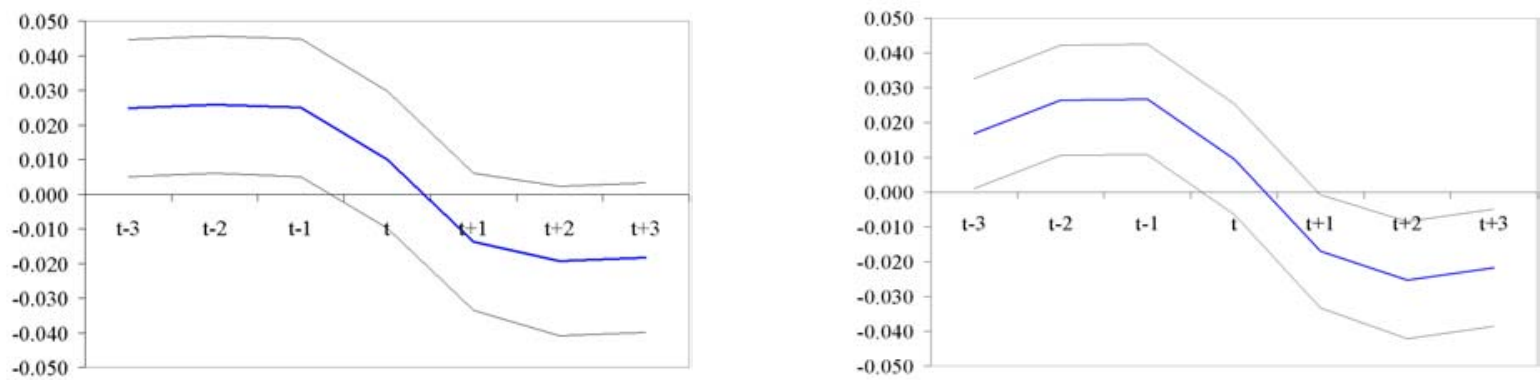

Consumption/GDP
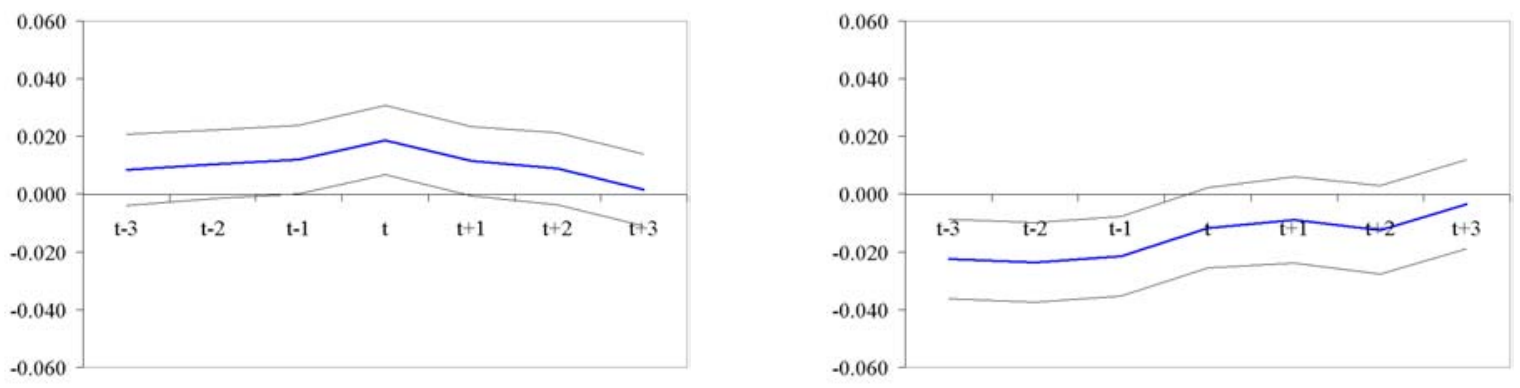

Note: Fixed and non-fixed regimes are determined according to the de facto classification by Levy-Yeyati and Sturzenegger (2001).

To see whether lending booms typically end with a 'soft landing,' not in a crash, we cannot center the analysis around a crisis as we have done so far. Instead, we need to consider all country/years and define what we mean by the beginning of a lending boom. There are several ways in which this can be done. We will say that a lending boom starts at $t$ if real credit grows by more than $10 \%$ per year during $t$ and $t+1$. Figure 10 depicts the typical lending boom. Panel (a) shows that if a boom starts at t, credit growth will be significantly above the HP trend for 6 years. Furthermore, after an initial buildup phase, credit growth starts to gradually decelerate at $t+4$ and it lands softly to its trend by $t+6$. Panel (b) shows that the same pattern arises if we look at real credit growth rates. In this case the duration of the boom is somewhat shorter but also fades out gradually.

Another way of investigating whether there is a soft landing is to look at conditional probabilities of crises and booms as we do in Table 1. Take the case in which a lending boom is a pair of country-years in which credit grows by $20 \%$ or more. Table 1 shows that crises tend to be preceded by booms: $p(l b \mid c r)=91 \%$. However, the converse is not true: if a boom starts at $t$, the probability of a crisis in either $t+2$ or $t+3$ is approximately $p(c r \mid l b)=6 \%$. This is a rather small number, although relatively much bigger than the probability of a 
crisis in tranquil times, which is $3.9 \%$.

To see whether financial liberalization is typically followed by a lending boom we use the liberalization dates of Bekaert et. al. (2001), and follow a similar procedure as in Figure 10. Panel (a) in Figure 11 shows that the growth rate of credit is significantly above its tranquil time mean for 5 years after liberalization. Panel (b) shows that starting in the third year after liberalization the deviation of real credit from its HP trend becomes significantly positive. ${ }^{19}$

\footnotetext{
${ }^{19}$ Since financial liberalization constitutes a structural break in the series, the interpretation of tranquil times is less clear. However for our purposes the dynamic pattern is relevant and the increase of credit after liberalization is clear regardless of the mean credit growth that exisits in the years not covered by the dummies in the regression.
} 
Figure 10: Soft Landing

a) Deviation from HP-Trend

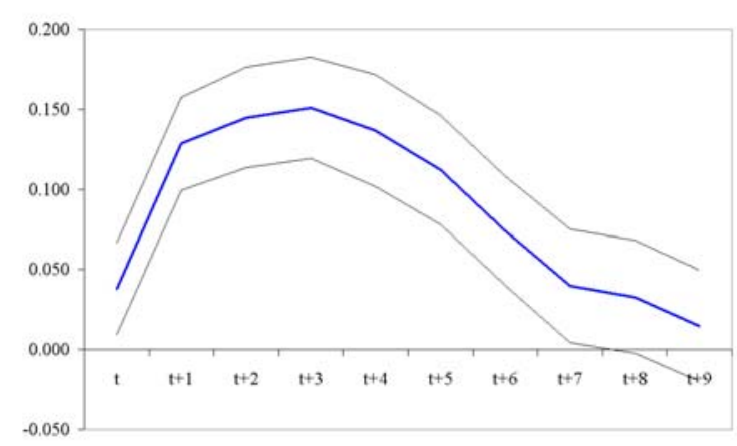

b) Growth rates

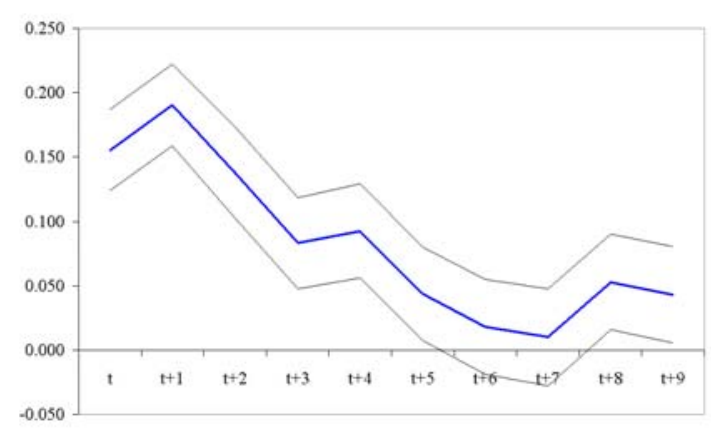

Note: Time $t$ in this figure corresponds to the 'beginning of a lending boom,' which is defined as the fist year of a period of at least 2 years in which there is more that $10 \%$ real credit growth per year.

\section{Figure 11: Real Credit after Financial Liberalization}

a) Deviation from an HP-trend

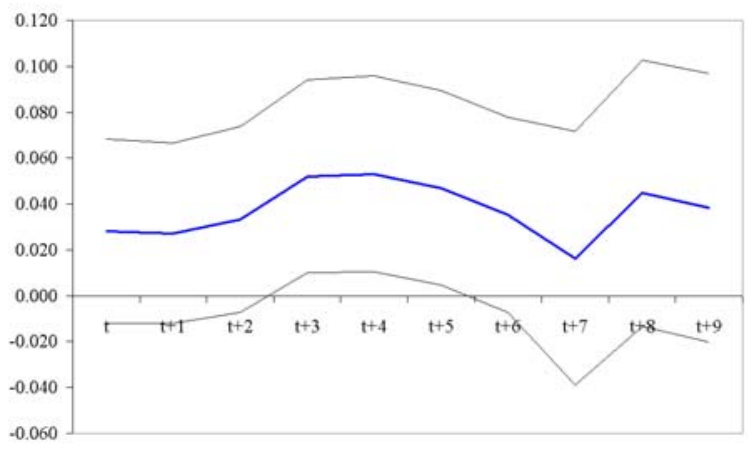

b) Growth rates

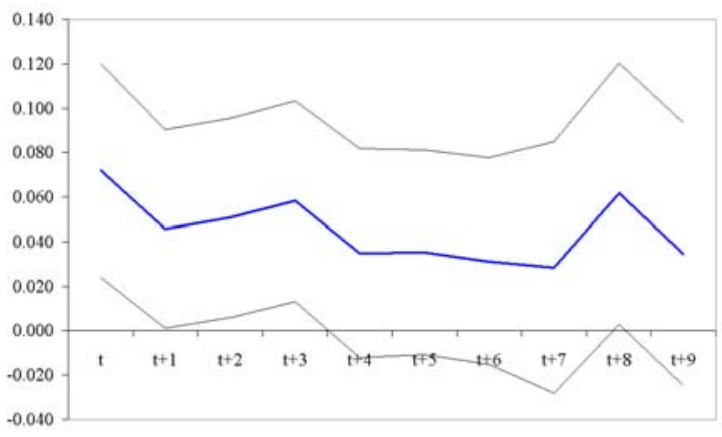

Note: Time $t$ in this figure corresponds to the date of financial liberalization. Dates for financial liberalization are taken from Baekert et.al (2001) 


\section{Table 1: Probability of a crisis given a lending boom (and vice versa)}

\begin{tabular}{l|ccc} 
& LB2 & LB3 & LB4 \\
\hline $\operatorname{Pr}($ crisis in j+1 $\mid$ LB (j)) & $6.9 \%$ & $6.7 \%$ & $6.7 \%$ \\
$\operatorname{Pr}($ crisis in j+2 $\mid$ LB (j)) & $6.3 \%$ & $5.6 \%$ & $8.9 \%$ \\
$\operatorname{Pr}($ crisis in j+3 LB (j)) & $5.7 \%$ & $5.6 \%$ & $6.7 \%$ \\
$\operatorname{Pr}($ crisis in tranquil times) & $3.9 \%$ & $4.6 \%$ & $4.6 \%$ \\
$\operatorname{Pr}($ LB $\mid$ Crisis $(j))$ & $91.1 \%$ & $51.7 \%$ & $31.0 \%$ \\
\hline
\end{tabular}

Note: LB2-LB4 denote three different definitions of a lending boom. LB2 is a period of a cumulative increase in real credit over the past 2 years of more than $20 \%$ (30\% for LB3 and $40 \%$ for LB4). $\operatorname{Pr}(\operatorname{crisis}$ in $\mathrm{j}+\mathrm{i} \mid \mathrm{LB}(\mathrm{j}))$ with $\mathrm{i}=1 . .3$ denotes the probability of a crisis during the year $\mathrm{j}+\mathrm{i}$. $\operatorname{Pr}$ (crisis in tranquil times) denotes the probability of a crisis in all other years. $\operatorname{Pr}(\mathrm{LB} \mid$ Crisis $(\mathrm{j}))$ denotes the probability that a lending boom was present within the 3 years before the crisis or during the year of the crisis .

\section{Comovements}

The event windows show the behavior of key several variables around twin crises. Here we characterize the comovements of key macro variables without conditioning on the occurrence of twin crises. We investigate whether during the last two decades there have been statistically significant co-movements between credit growth, the real exchange rate and the N-to- $\mathrm{T}$ output ratio in middle income countries. Also we investigate whether credit growth has been correlated with investment and GDP. For instance, does credit growth commove with the real exchange rate and the N-to-T output ratio? Does it commove with investment and GDP? We address this question by regressing real credit growth on several variables. The panel data estimation is implemented allowing for fixed effects and a GLS estimator. ${ }^{20}$ Again, we have our set of 39 countries in the cross section dimension and the period 1980-1999 in the time series dimension.

The first regression in Table 2 shows that an increase in credit is associated with (i) a real appreciation and (ii) an increase in the ratio of nontradables-to-tradables output. It is remarkable that these partial correlations are higly significant across different specifications. Correlation (i) indicates that there exist 'balance sheet effects': in the presence of a currency mismatch, a real appreciation deflates the debt burden. This increases cash flow and the ability to borrow. Correlation (ii) indicates that the N-sector is more 'credit-constrained' than the T-sector.

We also find that investment growth is statistically significant, but GDP growth is not. Interestingly, GDP enters the regression with a negative sign. This reflects the puzzle we have noted earlier: in the aftermath of crisis a credit crunch coexists with a recovery of aggregate GDP. To investigate this further we define the interaction term GDP*Dummy, where the dummy is equal to one in the period of the crisis, and in the following three

\footnotetext{
${ }^{20}$ All variables are in first differences in oder to avoid the issues associated with non-stationarity.
} 
periods, while it is equal to zero otherwise. Regression 4 shows that GDP*Dummy enters with a negative sign and is statistically significant, while GDP enters with a positive sign, but remains insignificant. As the sum of the two coefficients is clearly negative, credit and GDP are negatively correlated in the aftermath of crisis, while there exists no statistical relationship that adds to the information provided by investment, the real exchange rate and $\mathrm{N} / \mathrm{T}$, otherwise. Regression 5 shows that if GDP and GDP*Dummy are included without investment, the coefficient on GDP is positive and the one on the interaction dummy is negative. Both are significant.

It is likely that some of the explanatory variables are endogenous. In order to test for the robustness against the simultaneity problem, we estimated the model with two stage least squares, rather than OLS, using lagged variables as instruments. This yielded qualitatively similar results. The partial correlations reported in figure 2, of course, cannot be interpreted as causal relations. However the fact that a simple regression reveals the co-movements we have alluded to above is remarkable.

\section{Table 2: Comovements of real credit growth with other macro variables}

\begin{tabular}{|c|c|c|c|c|c|c|}
\hline Variable & & Reg. 1 & Reg. 2 & Reg. 3 & Reg. 4 & Reg. 5 \\
\hline 1/Real Exchange Rate & & 0.421 & 0.264 & 0.308 & 0.435 & 0.307 \\
\hline & St. Err. & 0.062 & 0.070 & 0.081 & 0.068 & 0.073 \\
\hline & P-val. & 0.000 & 0.000 & 0.000 & 0.000 & 0.000 \\
\hline $\mathrm{N} / \mathrm{T}$ & & 0.302 & 0.168 & 0.166 & 0.317 & 0.171 \\
\hline & St. Err. & 0.051 & 0.087 & 0.084 & 0.056 & 0.074 \\
\hline & P-val. & 0.000 & 0.056 & 0.049 & 0.000 & 0.022 \\
\hline Real Investment & & & 0.241 & 0.297 & & 0.327 \\
\hline & St. Err. & & 0.066 & 0.073 & & 0.067 \\
\hline & P-val. & & 0.000 & 0.000 & & 0.000 \\
\hline Real GDP & & & & -0.383 & 0.347 & 0.044 \\
\hline & St. Err. & & & 0.304 & 0.169 & 0.290 \\
\hline & P-val. & & & 0.210 & 0.041 & 0.881 \\
\hline Real GDP after crisis & & & & & -0.802 & -1.293 \\
\hline & St. Err. & & & & 0.317 & 0.382 \\
\hline & P-val. & & & & 0.012 & 0.001 \\
\hline Adjusted R-squared & & 0.340 & 0.377 & 0.377 & 0.353 & 0.407 \\
\hline Durbin-Watson stat. & & 1.670 & 1.600 & 1.605 & 1.670 & 1.693 \\
\hline
\end{tabular}

Note: Domestic credit is the dependent variable. All panel regressions are estimated using a GLS estimator and allowing for fixed effects. All variables enter the regression in growth rates. The variable "Real GDP after crisis" equals real GDP times a dummy that is equal to 1 from period $t$ to $t+3$, and is zero otherwise; where $t$ is the crisis time. Bold numbers represent significance at the $10 \%$ level. 


\section{Evidence on the Two Underlying Distortions}

In this section we present evidence on the two distortions that underlie the mechanism that generates boom-bust cycles: systemic guarantees and asymmetric financing opportunities across sectors.

\section{Implicit bailout guarantees}

Despite the fact that bailout guarantees have played an important role in several explanations of crises, there is no empirical evidence supporting the existence of this distortion. Although many countries have systemic guarantees in place, it is very difficult to document their existence directly. The difficulty in pinning guarantees down is that in most cases they are implicit. To begin with, systemic guarantees are not limited to promises to hand out a bailout payment to lenders in case of default. In most cases systemic guarantees are implicit in the exchange rate regime and monetary policy rules that are in place in a given country. Since in most instances one of the objectives of policymakers is to avoid sharps drops in output, they will implement policies that are, de facto, implicit guarantees against systemic crises. $^{21}$

The question arises as to how to go about finding implicit guarantees. We address this question by looking at the behavior of interest rate spreads. The idea is that if there exist guarantees, the spread will, ceteribus paribus, be insensitive to a deterioration in the average quality of loans, assuming of course, that no crisis has yet occurred. When a crisis occurs, the economy suffers a credit crunch and both the quality of loans collapses and the spread skyrockets.

An ideal way to measure the evolution of the loans' quality is with the 'true' share of non-performing loans (NPLs). Unfortunately, such data in time series form does not exist for most middle income countries. A good proxy for an increase in NPLs is the occurrence of a lending boom in the recent past. This is because when there is a sharp acceleration in credit, the monitoring capacity of both banks and regulators is diminished, so that there is an increase in the likelihood of granting credit to bad projects. The increase in the share of NPLs may take some time to materialize because it takes time for a given loan to become non-performing and because during the boom a lot of new loans are being granted. Nonetheless, after some time NPLs must become a problem for the banking system. This is true regardless of whether NPLs are officially recorded.

To capture this idea we run the following panel regression

$$
i_{j, t}=\alpha_{j}+\alpha_{1} L B_{j, t-1}+\alpha_{2} D_{j, t} \cdot L B_{j, t-1}+\varepsilon_{j, t},
$$

where $i_{j, t}$ is the real lending rate in country $j$ at time $t$, minus the federal funds rate of the United States. $L B_{j, t-1}$ is a dummy that indicates the existence of a lending boom. It is equal to one if during the past 2 years real credit has grown by more than $10 \%$ on average. $D_{j, t}$ is a dummy variable that indicates that a twin crisis has occurred at $t$ or $t-1$.

\footnotetext{
${ }^{21}$ Systemic bailout guareantees are not the same as deposit insurance schemes, which cover individual agents against idyosincratic risk.
} 
The coefficient $\alpha_{1}$ measures the effect of an increase in NPLs on the spread in countryyears in which a crisis has not occurred in either the current or the previous years. Meanwhile, the sum $\alpha_{1}+\alpha_{2}$ measures the effect of an increase in NPLs on the spread during crisis times (at $t$ or $t-1$ ). As we discussed above, in order to isolate the effect of guarantees we need to distinguish between periods in which a crisis has not occurred recently, and periods where a crisis has occurred recently. This is because systemic crises are typically preceded by lending booms and during crises the spread shoots up.

The null hypothesis that there are systemic guarantees is $H_{0}: \alpha_{1}=0$. Table 3 shows the estimates of regression (4.1). Panel (a) considers a set of eleven often studied countries, and panel (b) considers all middle income countries. In both cases we cannot reject the null at the $10 \%$ significance level. That is, we cannot reject the presence of implicit systemic guarantees. Interestingly, if the crisis dummy is disregarded and the interest rate is regressed only on the lending boom dummy, the estimated coefficient is statistically significant at the $10 \%$ level.

We would like to note that if we were to define systemic guarantees literally as promises to hand out a bailout payment to lenders in case of default, we could investigate the proportion of crises that have triggered this type of bailouts, and then impose rational expectations to infer the ex-ante implicit guarantee. Bordo and Schwarz (2001) survey the bailouts that have been granted during the last two decades and during the early banking crises of the 20th century. They find strong evidence of ex-post bailouts. ${ }^{22}$

\section{Table 3: Implicit Bailout Guarantees}

(Estimates of the panel regression: $i_{j, t}=\alpha_{j}+\alpha_{1} L B_{j, t-1}+\alpha_{2} D_{j, t} * L B_{j, t-1}+\varepsilon_{j, t}$ )

\begin{tabular}{|r|c|c|c|c|}
\hline & \multicolumn{2}{|c|}{ a) Group of 11 } & \multicolumn{2}{c|}{ b) Group of 39 } \\
\hline & Reg. 1 & Reg. 2 & Reg. 1 & Reg. 2 \\
\hline$L B_{\mathrm{j}, \mathrm{t}-1}$ & $\mathbf{1 . 3 5 5 0}$ & 0.6434 & $\mathbf{0 . 7 2 3 6}$ & -0.1883 \\
\hline St. Er. & 0.7693 & 0.7348 & 0.3488 & 0.4856 \\
\hline P-val. & 0.0805 & 0.3828 & 0.0416 & 0.6986 \\
\hline$D_{\mathrm{j}, \mathrm{t}} * L B_{\mathrm{j}, \mathrm{t}-1}$ & & $\mathbf{3 . 4 4 6 8}$ & & $\mathbf{2 . 8 3 3 6}$ \\
\hline St. Er. & & 1.0362 & & 1.0075 \\
\hline P-val. & & 0.0011 & & 0.0054 \\
\hline R-Square & 0.401 & 0.502 & 0.631 & 0.634 \\
\hline \# of obs. & 143 & 143 & 244 & 244 \\
\hline
\end{tabular}

Note: $i$ is the spread between the real lending rate and the US federal funds rate. The lending boom dummy, $L B$, is equal to one if the growth rate of real credit has been larger than $10 \%$ on average for the past two years. The crisis dummy, $D$, indicates that a twin crisis occurred in $t$ or $t+1$. The regressions are estimated with fixed effects, using a GLS estimator. Bold numbers represent significance at the $10 \%$ level.

\footnotetext{
${ }^{22}$ See also IMF (1998) and Jeanne and Zettelmeyer (2000).
} 


\section{Asymmetric Financing Opportunities}

In many middle income countries there is anecdotal evidence that most of the agents who are credit constrained and have access only to bank financing are in the N-Sector, whereas most firms that are unconstrained and have access to sources of finance other than banks, such as bond and equity markets, are in the T-Sector.

Evidence on asymmetries in financing opportunities exist for individual countries. For instance Ber, Blass and Oved (2002) show that in Isreal non-exporting firms are more credit constraint than exporting firms. To establish the existence of this asymmetry more generally, we use firm level data from a panel of 3877 firms, covering 27 out of our sample of 39 middle income countries. ${ }^{23}$ This data set is part of the World Business Economic Survey (WBES, 2001) of the World Bank. ${ }^{24}$

In this survey firms were classified according to their size and, among other things, were asked whether or not they export. ${ }^{25}$ Since the share of tradable output in the group of export firms is greater than that of non-export firms, it is reasonable to identify exporters with T-sector firms and non-exporters as N-sector firms. Using this classification we find that in most countries a majority of small firms belong to the N-sector, while a majority of large firms belong to the T-sector. ${ }^{26}$ In table 4 we see that in the set of 27 countries, $68 \%$ of small and medium firms belong to the N-sector, while $67 \%$ of the large firms belong to the T-sector.

\section{Table 4: Are Small firms N and Large firms T?}

\begin{tabular}{|l|l|l|}
\hline & Non Exporters & Exporters \\
\hline Small & $68 \%$ & $32 \%$ \\
\hline Large & $33 \%$ & $67 \%$ \\
\hline
\end{tabular}

Source: World Business Environment Survey (WBES), 2001.

Note: "small" denotes small and medium firms up to 200 employees. "large" firms have more than 200 employees.

Firms were also asked to rank on a scale from 1 to 4 , how much of an obstacle financing was to running their business. We use the answers from this survey to estimate an ordered probit model to assess whether there exists an asymmetry in financing opportunities across

\footnotetext{
${ }^{23}$ Argentina, Brazil, Chile, Czech Republic, Ecuador, Egypt, Estonia, Hungary, Indonesia, Lithuania, Mexico, Malaysia, Peru, Philippines, Poland, Portugal, Russia, Slovakia, Slovenia, South Africa, Spain, Sweden, Thailand, Thurkey, Tunesia, Uruguay and Venezuela.

${ }^{24}$ The data base is available from the World Bank at: http://www1.worldbank.org/beext/resources/assesswbessurvey-alt.htm

See Schiffer and Weder (2001) for a complete discription of the data base.

${ }^{25}$ Firms with up to 200 workers, are classified as small and medium enterprises (SME).

${ }^{26}$ There are some large firms that belong to the N-sector, such as utilities. However, in most countries they represent a small share of the firms in the N-sector that were surveyed.
} 
the $\mathrm{N}$ and T-sectors in middle income countries. ${ }^{27,28}$

We create a dummy variable for the yes-or-no answer "do you export?" A significant positive parameter on the dummy indicates that $\mathrm{N}$-sector firms evaluate the access to finance as a significantly larger obstacle to running their business than T-sector firms do. Table 5a reports the regression results for the basic regression, and table $5 \mathrm{~b}$ reports the results of a regression that includes two control variables: the age of the firm and the share of government participation.

In all regressions we find that there is a significant difference between exporters and non-exporters in their evaluation of obtaining financing as an obstacle for running their businesses. The latter evaluate the obstacle to be more severe. Furthermore, we find that among exporters, the larger the share of exports in output, the less significant is financing deemed to be as an obstacle for running a business.

We also find that older firms have easier access to financing than younger firms. The same is true for firms with a high government participation. None of the control variables, however, obviates the role of the exporters/non-exporters indicator.

\footnotetext{
${ }^{27}$ We estimate ordered probit regressions of the following form.

$$
\begin{aligned}
y_{i}^{*} & =\beta_{0}+\beta_{1} E X P O R T+\beta_{2} A G E+\beta_{3} G O V+\gamma_{1} d_{1 i}+\ldots+\gamma_{n} d_{n i}+\varepsilon_{i}, \\
\text { where } y_{i} & =\left\{\begin{array}{lll}
1 & \text { if } & y_{i}^{*}<\alpha_{1} \\
2 & \text { if } & \alpha_{1}<y_{i}^{*}<\alpha_{2} \\
3 & \text { if } & \alpha_{2}<y_{i}^{*}<\alpha_{3} \\
4 & \text { if } & \alpha_{3}<y_{i}^{*}
\end{array}\right\},
\end{aligned}
$$
}

$\mathrm{n} \in\{9,27\}$, and $E X P O R T$ is either a dummy that takes the value of 1 if the firm does not export, or it is share exports in output among exporting firms. GOV controls for government participation in the firm, $A G E$ denotes the year a firm was established and $d_{1} \ldots d_{n}$ are country dummies. The dependent variable, $y$, captures the ranking of the severity of an obstacle for running a business, as perceived by the firms. The obstacles considered are financing, collateral and the exchange rate. The true $\mathrm{y}$ is not directly observed and the $\alpha$ parameters are estimated together with $\beta_{0} \ldots \beta_{3}$ and $\gamma_{1} \ldots \gamma_{n}$.

${ }^{28}$ We use the same approach as Schiffer and Weder (2001), who compare small and large firms with respect to financing constraints as well as other indicators of goverance. They find that small firms are more financing constrained. 
Table 5: Asymmetric Financing Opportunities (Evidence from firm level data)

(Estimates of an ordered probit regression)

(a) Tradable vs. Non-tradable:

\begin{tabular}{|l|c|c|c|c|}
\hline & \multicolumn{2}{|l|}{$\begin{array}{l}\text { a) 9 often studied } \\
\text { countries: }\end{array}$} & \multicolumn{2}{l|}{$\begin{array}{l}\text { b) 27 Middle income } \\
\text { countries: }\end{array}$} \\
\hline & Coefficient & \#obs & Coefficient & \#obs \\
\hline Regression 1: & & & & \\
\hline N-sector firms & $\begin{array}{c}\mathbf{0 . 1 8 5} \\
(0.070)\end{array}$ & 1101 & $\begin{array}{c}\mathbf{0 . 1 7 5} \\
(0.039)\end{array}$ & 3446 \\
\hline Regression 2: & & & & \\
\hline $\begin{array}{l}\text { Share of } \\
\text { exports among } \\
\text { T-sector firms }\end{array}$ & $\begin{array}{c}\mathbf{- 0 . 0 0 7} \\
(0.001)\end{array}$ & 506 & $\begin{array}{c}\mathbf{- 0 . 0 0 3} \\
(0.001)\end{array}$ & 1342 \\
\hline
\end{tabular}

Note: Ordered Probit regressions are specified with a constant and with country dummies. The dependent variable is the answer to the question "is financing a major obstacle to running your business?". The answer is evaluated on a scale from 1 to 4 . The independent variable in Regression 1 is a dummy that is equal to one for $\mathrm{N}$ sector firms and zero otherwise. In regression 2 , it is the share of exports among $\mathrm{T}$-sector firms. Bold numbers represent significance at the $10 \%$ level. The standard errors are reported in parenthesis below the point estimates.

Table 5: continued

(b) Other control variables: Small vs. Large Firms, Age and Government Participation

\begin{tabular}{|l|c|l|c|l|}
\hline & \multicolumn{2}{|l|}{$\begin{array}{l}\text { c) } 9 \text { often studies } \\
\text { countries: }\end{array}$} & \multicolumn{2}{l|}{$\begin{array}{l}\text { d) 27 Middle income } \\
\text { countries: }\end{array}$} \\
\hline & Coefficient & & Coefficient & \\
\hline Regression 3: & & & & \\
\hline NL & $\mathbf{0 . 1 4 0}$ & & $\mathbf{0 . 2 6 5}$ & \\
& $(0.077)$ & & $(0.051)$ & \\
\hline NS & $\mathbf{0 . 1 9 8}$ & & $\mathbf{0 . 0 9 4}$ & \\
& $(0.087)$ & & $(0.053)$ & \\
\hline Age & $\mathbf{- 0 . 0 0 4}$ & & -0.000 & \\
& $(0.001)$ & & $(0.001)$ & \\
\hline Government & -0.001 & & $\mathbf{- 0 . 0 0 4}$ & \\
& $(0.003)$ & & $(0.001)$ & \\
\hline
\end{tabular}

Note: Regression 3 is estimated as regressions 1 and 2, but including the following independent variables: $\mathrm{NL}=$ Non-tradable and large, NS=Non-tradable and small, the age of the firm and the share of government participation. Also see notes to panel (a). 


\section{Conceptual Framework}

To explain some of the stylized facts that we have described 'third generation' crises models have looked to financial market imperfections as key 'fundamentals'. The models are typically based on one of two distortions: either "bad policy", in the form of bailout guarantees, or "bad markets", in the form asymmetric information, or the imperfect enforceability of contracts in financial markets. ${ }^{29}$ On the one hand, bailout guarantees lead agents to undertake excessive risk. This can explain dollar denominated debt and overinvestment. On the other hand, financial frictions lead lenders to be very conservative and give rise to credit constraints. This can explain credit crunches and underinvestment. In general, these distortions neutralize each other: when guarantees are present lenders might not care whether a borrower will repay. Thus, credit constraints will not arise in equilibrium.

Schneider and Tornell (2000), henceforth ST, consider an economy where these two distortions do not neutralize each other and show how their interaction generates several features of the boom cycle, as well as the comovements alluded to above. In this section we present some elements of ST's model that will be useful to rationalize the dynamic patters observed along boom cycles.

There are two goods in the economy: a tradable $(\mathrm{T})$ and a nontradable $(\mathrm{N})$. We will denote their relative price (i.e., the inverse of the real exchange rate) by $p_{t}=\frac{p_{N, t}}{p_{T, t}}$.

The model has three distinctive features. First, the only source of uncertainty is endogenous real exchange rate risk: in equilibrium $p_{t+1}$ might equal $\bar{p}_{t+1}$ with probability $\alpha$ or $\underline{p}_{t+1}$ with probability $1-\alpha$. This captures the fact that crises are typically not preceded by large exogenous shocks. The second feature is that only N-sector agents may be subject to credit constraints. This captures the fact that in middle income countries T-sector firms have easy access to external finance because they can either pledge export receivables as collateral, or can get guarantees from closely linked firms. In contrast, collateralized bank credit is practically the only source of external finance for small and N-sector firms. The third feature is that there are systemic bailout guarantees.

\section{The N-Sector}

There is a continuum of firms run by overlapping generations of managers. These firms produce $\mathrm{N}$-goods using only $\mathrm{N}$-goods as inputs according to a linear production technology

$$
q_{t+1}=\theta I_{t}
$$

Investment $I_{t}$ is financed with internal funds $w_{t}$ and with debt. In order to model the debt-denomination decision N-sector agents are allowed to issue either 'risky debt' or 'safe debt'. Risky debt is denominated in T goods (foreign currency) on an unhedged basis, while safe debt is denominated in $\mathrm{N}$ goods. To make matters concrete it is assumed that the

\footnotetext{
${ }^{29}$ See for instance, Aghion, Bacchetta and Banerjee (2000), Burnside, Eichenbaum and Rebelo (2000), Caballero and Krishnamurthy (1999), Calvo (1998), Corsetti, Pesenti and Roubini (1999), Krugman (1999) and Mckinnon and Pill (1998).
} 
representative firm begins period $t$ with internal funds $w_{t}$, and raises an amount $b_{t}+b_{t}^{n}$ by issuing one-period bonds that pay off in T-goods and N-goods, respectively. The promised repayment is

$$
L_{t+1}+p_{t+1} L_{t+1}^{n}=\left(1+\rho_{t}\right) b_{t}+p_{t+1}\left(1+\rho_{t}^{n}\right) b_{t}^{n}
$$

Since $b_{t}$ and $b_{t}^{n}$ are measured in T-goods, the budget constraint is

$$
p_{t} I_{t}=w_{t}+b_{t}+b_{t}^{n}
$$

At time $t+1$ a firm's cash flow in terms of T-goods is

$$
\pi\left(p_{t+1}\right):=p_{t+1} \theta I_{t}-L_{t+1}-p_{t+1} L_{t+1}^{n}
$$

If the firm is solvent $\left(\pi\left(p_{t+1}\right)>0\right)$, the manager pays out a fraction $c$ of profits as dividends to himself and passes on the remainder to the next manager. If a firm is insolvent (i.e., $\left.\pi\left(p_{t+1}\right)<0\right)$, all returns are dissipated in the bankruptcy procedure. In this case the new cohort of managers receives an 'aid payment' $e$ to jump start their firms. Lastly, in period 0 there is both a cohort of initial incumbent managers who have an amount $q_{0}$ of nontradables to sell and a cohort of new managers who have an endowment $e_{0}$ in terms of tradables. It follows that internal funds evolve according to $w_{0}=e_{0}$, and for $t \geq 1$ :

$$
w_{t}= \begin{cases}{[1-c] \pi\left(p_{t}\right)} & \text { if } \pi\left(p_{t}\right)>0 \\ e & \text { otherwise }\end{cases}
$$

\section{Distortions}

$\mathrm{N}$-sector financing is subject to two distortions: contract enforceability problems and bailout guarantees. It is well known that in an economy in which only enforceability problems are present, like in standard financial accelerator models, the amount of credit available to a firm is determined by its internal funds $\left(w_{t}\right){ }^{30}$

Let us introduce bailout guarantees. If all debt were covered by 'unconditional' guarantees (i.e., if bailouts were granted whenever there is an individual default), then enforceability problems would not generate credit constraints because lenders would be bailed out in all states of the world. Thus, in order for credit constraints to arise in equilibrium some portion of debt must be covered only by 'systemic' bailout guarantees. That is, bailouts are granted only if a critical mass of agents defaults. For concreteness we assume that a bailout occurs if and only if more than $50 \%$ of firms are insolvent $\left(\pi\left(p_{t+1}\right)<0\right)$ in a given period. During a bailout an international organization pays lenders a fraction $F \in\{0,1\}$ of the outstanding debts of all defaulting managers, regardless of debt-denomination (N- or T-goods).

\section{The T-sector}

The N-sector will take center stage in the model. For our purposes it is sufficient to think of the T-sector as a group of agents that demands N-goods $\left(D_{t}\right)$ and produces tradable

\footnotetext{
${ }^{30}$ See Bernanke et. al. (2000).
} 
goods $\left(q_{t}^{t r}\right)$. What is important for the argument is that the demand function for N-goods be downward-sloping and that it be expected to increase at some point in the future. Thus, we assume that $D_{t}\left(p_{t}\right)=\frac{d_{t}}{p_{t}}$. Hence, the market clearing condition for non-tradables is

$$
\frac{d_{t}}{p_{t}}+I_{t}=q_{t}^{n}
$$

where $I_{t}$ is the investment demand of the N-sector. The supply of T-goods $q_{t}^{t r}$ will play no role in the model. In fact $q_{t}^{t r}$ will only appear in Section 6 when we refer to the gross domestic product: $G D P_{t}=q_{t}^{t r}+p_{t} q_{t}^{n t}$. In order to link the model to the facts in Section 6 , it will not be necessary that $q_{t}^{t r}$ be decreasing in $p_{t}$. We thus simply assume that $q_{t}^{t r}$ follows a linear trend: $q_{t}^{t r}=\varepsilon q_{t-1}^{t r}$, where $\varepsilon$ is an arbitrary constant.

\subsection{Currency Mismatch and Endogenous Real Exchange Rate Risk}

The first main result of ST is that the interaction of systemic bailout guarantees and enforceability problems can generate endogenous real exchange rate risk. This is because there is a self-reinforcing mechanism at work. On the one hand, if there is sufficient real exchange rate risk: (a) credit constraints arise and (b) it is individually optimal for an N-sector agent to issue risky T-debt (i.e., borrow in foreign currency on a short-term and unhedged basis). On the other hand, if many N-sector agents gamble by denominating their debt in $\mathrm{T}$ goods, exchange rate risk might be endogenously created, as the economy becomes vulnerable to self-fulfilling meltdowns of the banking system. If the amount of $\mathrm{T}$ denominated debt is high, a real depreciation can severely squeeze cash flow, or even bankrupt banks altogether. Since they face binding borrowing constraints, they then have to curtail lending to the Nsector. Weak investment demand from the N-sector for its own products in turn validates the real depreciation. The systemic credit risk created by the banking system thus induces endogenous exchange rate risk.

\section{Risky Debt Denomination}

Suppose that there is enough real exchange rate variability in the sense that $\bar{p}_{t+1}$ will be high enough so as to make the production of N goods a positive NPV activity, while $\underline{p}_{t+1}$ will be low enough so as to bankrupt firms with T-debt on their books $\left(\pi\left(\underline{p}_{t+1}\right)<0\right)$. ST show that in this case lenders constrain credit to ensure that borrowers will repay in the no-crisis state, and borrowers find it optimal to denominate all debt in T-goods. Since the bailout agency will repay lenders in the crisis state, the expected repayment per unit debt is lower for T-debt than for N-debt. Another advantage of T-debt is that the firm can borrow more:

$$
\bar{b}_{t}^{n}=H^{s} w_{t}, \quad \bar{b}_{t}=H^{r} w_{t}, \quad 0<H^{s}<H^{r}
$$

This is because since shifting from $\mathrm{N}$ to $\mathrm{T}$ - debt reduces the expected debt burden, lenders are willing to lend more at each level of internal funds.

A disadvantage of T-debt is that it might lead to insolvency. Since there are bankruptcy costs, when there are no bailout guarantees, it is optimal for an agent to denominate all debt 
in N-goods. However, if crises are rare events ( $\alpha$ is large) and bailouts are generous ( $F$ is large), then it is individually optimal to denominate debt in $\mathrm{T}$ goods.

Since the production of N-goods is a positive NPV activity, managers will borrow as much as possible and set investment expenditure equal to $p_{t} I_{t}=w_{t}+\bar{b}_{t}+\bar{b}_{t}^{n}$. Using (5.7) we obtain the well known result that investment of a credit constrained firm depends not only on the rate of return, but also on cash flow:

$$
I_{t}=m_{t} \frac{w_{t}}{p_{t}}, \quad m_{t}=\left\{\begin{array}{cl}
m^{s} & \text { if } b_{t}=0 \\
m^{r} & \text { if } b_{t}^{n}=0
\end{array}\right.
$$

where $m_{t}=1+H_{t}$ denotes the investment multiplier.

\section{Real Exchange Rate Risk}

Next we reverse the question and ask when is it that a risky debt structure can generate real exchange rate risk. Suppose that incumbent managers enter the current period with a supply of nontradables $q_{t}$ and a debt burden $L_{t}+p_{t} L_{t}^{n}$.

As long as incumbents are solvent, internal funds are $w_{t}=(1-c) \pi_{t}$, where $\pi_{t}=p_{t} \theta I_{t}-$ $L_{t}-p_{t} L_{t}^{n}$. In contrast, if the bad state is realized and firms become insolvent, the new cohort starts out with an endowment $e$ of $\mathrm{T}$ goods. Investment expenditure is thus $p_{t} I_{t}=$ $\eta_{t}\left[p_{t} q_{t}-L_{t}-p_{t} L_{t}^{n}\right]$ if $p_{t} q_{t} \geq L_{t}+p_{t} L_{t}^{n}$, or $p_{t} I_{t}=m_{t} e$ otherwise (the cash flow multiplier $\eta_{t}$ is defined by $\left.\eta_{t}:=(1-c) m_{t}\right)$.

The equilibrium real exchange rate equalizes total demand for and the supply of nontradables. Since the T-sector's demand for non-tradables is equal to $d_{t} / p_{t}$,

$$
p_{t} q_{t}= \begin{cases}d_{t}+\eta_{t}\left[p_{t} q_{t}-L_{t}-p_{t} L_{t}^{n}\right] & \text { if } p_{t} q_{t} \geq L_{t}+p_{t} L_{t}^{n} \\ d_{t}+m_{t} e & \text { otherwise }\end{cases}
$$

Since supply is predetermined $\left(q_{t}=\theta I_{t-1}\right)$, the key to having multiple equilibria is a backward bending aggregate demand curve, as in Graph 1 . This is impossible if there is only N-debt $\left(L_{t}=0\right)$. However, multiple equilibria are possible if there is T-debt (and $L_{t}^{n}=0$ ). In this case price movements affect revenues, but keep the debt burden unchanged. For prices below the cutoff price $p_{t}^{c}=\frac{L_{t}}{q_{t}}$, all N-firms go bankrupt, and total demand is downward sloping. In contrast, for prices above $p_{t}^{c}$, investment demand is increasing in price. ST show that this makes total demand 'bend backward' and cross the supply schedule twice (as in Graph 1) if and only if

$$
L_{t}>d_{t}+m_{t} e \quad \text { and } \quad \eta_{t}>1
$$

A 'strong balance sheet effect' $\left(\eta_{t}>1\right)$ means that an increase in N-sector's cash flow induces a more than proportional increase in the N-sector's expenditure on its own goods. As we shall see, $\eta_{t}>1$ is not only necessary for self-fulfilling crises, but it is also key for the existence of lending booms. 


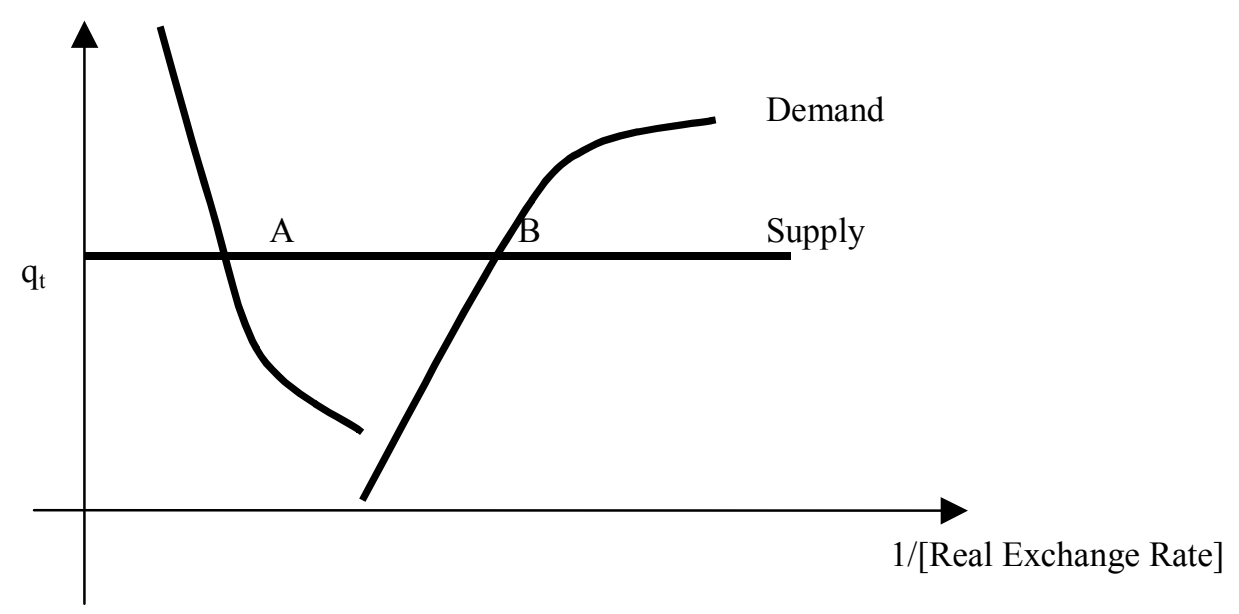

\subsection{Equilibrium Dynamics}

We have seen that if there is enough expected real exchange rate variability, then agents choose a risky debt denomination. Furthermore, in the presence of a enough T-debt, there are multiple possible values for the real exchange rate. In this subsection we will exhibit an equilibrium along which these elements belong a consistent dynamic story.

Consider a typical period $0<t<T-1$ during which all inherited debt is denominated in $\mathrm{T}$ goods and agents believe that at $t+1$ there will be a crisis with probability $1-\alpha$. Since in the good state in period $t$ firms are solvent, internal funds are given by $\bar{w}_{t}=$ $(1-c)\left(\bar{p}_{t} q_{t}-L_{t}\right)$. Since the debt burden equals $(1+r) b_{t-1}=(1+r) H^{r} w_{t-1}$ and output is $q_{t}=\theta I_{t-1}=\frac{\theta m^{r} w_{t-1}}{p_{t-1}}$, it follows that any equilibrium path of N-output and internal funds $\left(q_{t}, w_{t}\right)$ must be a solution to

$$
\begin{array}{rlrl}
q_{t}=\theta \frac{m^{r} w_{t-1}}{m^{r} w_{t-1}+d} q_{t-1} & & t \leq T \\
w_{t}=\frac{1-c}{\eta^{r}-1}\left[(1+r) H^{r} w_{t-1}-d\right], & t<T
\end{array}
$$

with initial conditions $q_{0}$ and $w_{0}=e_{0}$, and where $\eta^{r}=(1-c) m^{r}>1$ is the risky cash flow multiplier. The solution to (5.11)-(5.12) determines the 'lucky path,' along which no crisis occurs. The sequences of high and low prices associated with the lucky path are:

$$
\bar{p}_{t+1}=\frac{d+m^{r} w_{t+1}}{q_{t+1}} \quad \text { and } \underline{p}_{t+1}=\frac{d+m^{s} e}{q_{t+1}} \quad 1 \leq t<T
$$


The lucky path is part of an equilibrium provided that along this path agents expect: $(i)$ a sufficiently low price during a crisis, so that it is possible to claim the bailout subsidy by choosing a risky debt denomination that leads to insolvency in the bad state $\left(\pi\left(\underline{p}_{t+1}\right)<0\right)$; (ii) a sufficiently high return on investment in the absence of a crisis $\left(\theta \bar{p}_{t+1} / p_{t}>1+r\right)$, and (iii) a sufficiently low probability of a crisis $(\alpha>\underline{\alpha})$, which ensures that the ex-ante expected return is high enough and credit constraints bind.

Since during a crisis, internal funds of the new cohort are $\underline{w}_{t+1}=e, \pi\left(\underline{p}_{t+1}\right)<0$ is equivalent to $\underline{p}_{t+1} q_{t+1}-L_{t+1}=d+m^{r} e-(1+r) H^{r} w_{t-1}<0$. This condition holds provided $w_{t-1}$ is high enough.

The return $\theta \bar{p}_{t+1} / p_{t}$ is high enough provided investment demand grows sufficiently fast relative to supply. Since tomorrow's supply is determined by today's investment, tomorrow's investment must grow fast enough. But, since borrowing constraints bind, this can only happen if internal funds grow fast enough. How can we ensure this will happen? It is apparent from (5.12) that if $w_{t}$ is increasing over time, it will do so at an increasing rate. Thus, if initial internal funds $e_{0}$ are above a certain threshold and $\alpha$ is large enough, investment will have a positive NPV for all $t<T-1$ provided, of course, that investment is profitable at $T-1$. This is the case if the future increase in the demand for N-goods is large enough so as to allow the $\mathrm{N}$-sector to repay its accumulated debt at time $T$.

Suppose that a crisis hits at some time $\tau<T-1$. At the time of crisis internal funds collapse to $e$. Thereafter, managers will choose safe plans and will invest in N-production if the return is high enough. Along the post-crisis path all debt will be denominated in Ngoods, so the debt burden will be $(1+r) H^{s} w_{t-1}$. Thus, N-output and internal funds evolve according to (5.11)-(5.12) replacing $m^{r}$ by $m^{s}$, with initial conditions $q_{\tau}=\theta I_{\tau-1}$ and $w_{\tau}=e$.

ST show that if initial internal funds are high enough $\left(e_{0}>\underline{e_{0}}(d)\right)$, there is a range of crisis probabilities, $(1-\alpha) \in\left(0,1-\underline{\alpha}\left(e_{0}\right)\right)$, for which internal funds increase over time, agents choose a risky debt structure and a crisis can occur during the next period with conditional probability $1-\alpha$. Along the lucky path the N-sector expands, running a deficit in anticipation of strong T-sector demand in the future. Debt and investment expenditure rise over time as the $\mathrm{N}$-sector issues new debt to cover the sequence of deficits. A large shift in the T-sector demand in the final period $\left(\hat{d}>\underline{d}\left(e_{0}, \alpha, T\right)\right)$ ensures that the accumulated debt can be repaid in case no crisis had occurred by $T-1$. Finally, if a crisis occurs at some time $\tau$, the economy follows a safe path thereafter.

\section{Linking the Model to the Stylized Facts}

In this section we show that the evolution of the model economy along the equilibrium path resembles the typical boom-bust cycle described in Section 2.

If there is a strong balance sheet effect $\left(\eta_{t}>1\right)$, both the value of N-output $\left(p_{t} q_{t}^{n t}=\right.$ $\left.d+m^{r} w_{t}\right)$ and N-sector's internal funds $w_{t}$ rise as long as no crisis occurs. Since along the equilibrium path there are binding borrowing constraints, credit is determined by N-sector's internal funds: $b_{t}=\left(m^{r}-1\right) w_{t}$. Therefore, credit follows the same path as $w_{t}$. Initially credit grows slowly, but it accelerates over time. This might generate a lending boom along which 
the credit-to-GDP ratio increases. To see this note that GDP equals $q_{t}^{t r}+p_{t} q_{t}^{n t}$. Thus, in equilibrium the credit-to-GDP ratio is given by

$$
\frac{b_{t}}{G D P_{t}}=\frac{\left(m^{r}-1\right) w_{t}}{\varepsilon q_{t-1}^{t r}+d+m^{r} w_{t}}
$$

Since internal funds grow at an increasing rate (because there is a strong balance sheet effect), the credit-to-GDP ratio may follow an increasing path from some point on provided the growth rate of tradables production $\varepsilon$ is not too large.

In order to match the stylized fact that prior to a crisis a real appreciation coincides with a lending boom it is necessary that both $p_{t}$ and the credit-to-GDP ratio rise along the lucky path. Although the value of output $\left(p_{t} q_{t}\right)$ grows, $p_{t}$ and $q_{t}$ need not rise simultaneously. The technology parameter $\theta$ in (5.1) determines how the rise in value translates into changes in prices and quantities. If $\theta$ were very high, supply would outpace demand. As a result the price would fall over time, while investment would rise. Thus, in order for the real exchange rate to appreciate it is necessary that $\theta$ be low enough.

A strong balance sheet effect also implies that a self-fulfilling real depreciation can lead to widespread bankruptcies in the N-sector and a protracted credit crunch. If a crisis occurs at $\tau$, the real exchange rate depreciates from $\bar{p}_{\tau-1}=\frac{d+m^{r} w_{\tau-1}}{q_{\tau-1}}$ to $\underline{p}_{\tau}=\frac{d+m^{s} e}{q_{\tau}}$, N-sector firms become insolvent and internal funds collapse to a level $e$. This generates a drop in investment that validates the real depreciation.

Let us define a 'credit-crunch' as a declining path of the credit-to-GDP ratio. Since in the aftermath of a crisis internal funds collapse $\left(w_{\tau}=e\right)$, the growth rate of credit falls (because a strong balance sheet effect implies that $w_{t} / w_{t-1}$ is increasing in $\left.w_{t}\right)$. On the other hand, the growth rate of tradables production remains unchanged. As a result, in the aftermath of crisis the credit-to-GDP ratio follows a declining path for a while until internal funds recover. Note that if $e$ is below a critical level, GDP declines at the time of the crisis. Thereafter, the recession might continue for a few more periods. However, since the T-sector continues to grow in the aftermath of a crisis, a resumption of GDP growth can coexist with a deepening credit crunch.

Now consider the asymmetric sectorial pattern: the N-sector outperforms the T-sector during the boom, while the opposite is true during the bust. In the model T-output grows at a rate: $g^{t r}=\varepsilon-1$, while the growth rate of N-output $\left(g_{t}^{n t}=\frac{q_{t}}{q_{t-1}}-1\right)$ is given by (5.11). Thus the growth differential is given by

$$
g_{t}^{n t}-g^{t r}=\frac{\theta m_{t} w_{t-1}}{m_{t} w_{t-1}+d}-\varepsilon
$$

This equation states that the fraction of N-production that is invested by the N-sector depends on the financial strength of the N-sector. If internal funds are low, N-firms can borrow very little. Holding supply fixed, weak investment demand implies that the price is low and the T-sector absorbs a large fraction of N-output. Thus, there can be an initial period during which the T-sector outpaces the N-sector. However, along the lucky path 
internal funds grow gradually. Thus, the N-sector is able to borrow more over time, and is able to bid a greater share of N-supply away from the T-sector. In other words, both $w_{t}$ and $g_{t}^{n t}$ accelerate over time. Therefore, if the boom lasts long enough, there is a time when the $\mathrm{N}$-sector will start to grow faster than the T-sector provided $\varepsilon$ is not too large.

The collapse in N-firms' internal funds during a crisis leads to a fall in both N-output and its growth rate $\left(g_{\tau+1}^{n t}<0\right)$. Thereafter, if $\varepsilon$ is relatively high, $g_{t}^{n t}$ will remain below $g^{t r}$ for a while until internal funds have grown sufficiently. We thus have a simple version of the asymmetric sectorial pattern that actually takes place during boom-bust cycles. Clearly, in a less stylized model, in which T-production is decreasing in $p_{t}$, the amplitude of the cycles experienced by the N-to-T output ratio would be greater.

Finally, we would like to emphasize that the typical lending boom in the model economy need not end in crisis. Furthermore, the likelihood of self-fulfilling crises is not a free parameter. ST show that equilibria exist only if the probability of crisis during a given period $(1-\alpha)$ is small. If crises were not rare events, binding borrowing constraints would not arise in the first place. 


\section{Conclusions}

This paper makes three key points. First, the macroeconomic patterns experienced by middle income countries during the last two decades have many features that are common across this set of countries. Financial liberalizations have been typically followed by lending booms that sometimes end in twin currency and banking crises. Interestingly, the co-movements of key macroeconomic variables have not been significantly different across countries that have fixed exchnage rate regimes and those that do not.

The second point is that these co-movements are quite different from the ones observed in countries with well developed financial markets like the US. They reflect an asymmetry in financing opportunities across tradable and nontradables sectors, a severe currency mismatch and strong balance sheet effects.

The third point we make is that the co-movements of credit, the real exchange rate and the ratio of nontradables-to-tradables output, as well as the occurrence of twin crises can be rationalized by combining credit market imperfections with institutions that cover private losses during systemic crises.

Lots of empirical work remains to be done in order to better characterize the mechanisms that underlie the boom-bust cycle. For instance, it is important to develop firm level data sets that will cover several countries and that will allow us to classify firms along several dimensions (for instance, small vs. large, nontradables vs. tradables, etc.). Furthermore, these data sets should allow researchers to obtain information regarding investment opportunities and sources of external finance (e.g., bank credit, equity, bonds). Most of the existent data sets only include firms that are listed in stock exchanges. Since in middle income countries the listed firms are typically the largest firms, most of the existent data sets exclude small and medium sized enterprises.

Finally, it is important to have a better understanding of the types of bailout guarantees which are prevalent in different economies. Bailout guarantees are not limited to explicit promises to bailout creditors in case of default by borrowers. More generally, guarantees are implicit in exchange rate and monetary policies intended to avoid drastic declines in aggregate output and to safe the financial system from systemic shocks. 


\section{References}

[1] Aghion, Philippe, Philippe Bachetta, and Abhijit Banerjee (2000), "Capital Markets and the Instability of Open Economies," mimeo, Study Center Gerzensee.

[2] Bekaert, G. and H. Campbell (2001), "Economic Growth and Financial Liberalization," mimeo.

[3] Ber, Hedva, Asher Blass and Oved Yosha (2002), "Monetary Policy in an Open Economy: The Differential Impact of eExporting and Non-Exporting Firms," mimeo.

[4] Berger, H., J. de Haan and J. E. Sturm (2000), "An empirircal Investigation into Exchange Rate Regime Choice and Exchange Rate Volatillity," CESifo Working Paper 263.

[5] Bernanke, Ben, Mark Gertler and Simon Gilchrist (2000), "The Financial Accelerator in a Quantitative Business Cycle Framework" in Handook of Macroeconomics, Taylor and Woodford eds.

[6] Betts, Caroline M. and Timothy J. Kehoe (2001), " Real Exchange Rate Movements and the Relative Price of Nontraded Goods," Federal Reserve Bank of Minnieapolis Research Department Staff Report.

[7] Bordo, Michael D. and Anna J. Schwartz (2001) "Measuring Real Economic Effects of Bailouts: Historical Perspectives on How Countries in Financial Distress Have Fared With and Without Bailouts" NBER working paper 7701.

[8] Borensztein, Eduardo and Jong-Wha Lee (2000), "Financial Crisis and Credit Crunch in Korea: Evidence from Firm Level Data," IMF Working Paper.

[9] Burnside, Craig, Martin Eichenbaum and Sergio Rebelo, (2000), "Prospective Deficits and the Asian Currency Crisis," Journal of Political Economy, 109(6), December 2001, pages $1155-97$.

[10] Caballero, Ricardo and Arvind Krishnamurthy (1999), "International and Domestic Collateral Constraints in a Model of Emerging Market Crises," Journal of Monetary Economics, 48(3), December 2001, pages 513-48.

[11] Calvo, Guillermo (1998), "Capital Flows and Capital Market Crises: The Simple Economics of Sudden Stops," Journal of Applied Economics, pp 35-54.

[12] Caprio, G. and D. Klinguebiel (1997), "Bank Insolvency: Bad Luck, Bad Policy or Bad Banking" in M.Bruno and B. Plaskovic, eds., Annual World Bank Conference on Developing Economics, 1996, World Bank Washington, DC.

[13] Chang, R. and A. Velasco (1998), "Financial Crises in Emerging Markets: A Canonical Model," NBER working paper 6606. 
[14] Chinn, Menzie D. and Kenneth M. Kletzer (2000), "International Capital Inflows, Domestic Financial Intermediation and Financial Crises under Imperfect Information," NBER Working Paper 7902.

[15] Corsetti, Giancarlo, Paolo Pesenti and Nouriel Roubini (1999), "Paper Tigers: A Model of the Asian Crisis" European Economic Review 43(7), 1211-1236.

[16] Diamond D. and R. Rajan (2000), "Banks, Short Term Debt and Financial Crises," NBER working paper 7764.

[17] Demirguc-Kunt, A., E. Detragiache, and P. Gupta (2000), "Inside the Crisis: An Empirical Analysis of Banking System in Distress," IMF Working Paper 00/156.

[18] Eichengreen, Barry, Andrew Rose and Charles Wyplosz (1995), "Exchange Market Mayhem: The Antecedents and Aftermath of Speculative Attacks," Economic Policy, Vol. 21(October), 249-312.

[19] Engel, Charles (1999), "Accounting for U.S. Real Exchange Rate Changes," Journal of Political Economy, 107, 507-538.

[20] Forbes, Kristin J. (2002) „How Do Large Depreciations Affect Firm Performance?" MIT mimeo.

[21] Gelos, Gaston and Alejandro Werner (2002), Financial liberalization, credit constraints, and collateral: investment in the Mexican manufacturing sector, Journal of Development Economics, 67 (1): 1-2\%.

[22] Frankel, Jeffrey A., and Andrew K. Rose (1996), "Currency Crashes in Emerging Markets: An empirical Treatment." Journal of International Economics, 41(3): 351-366.

[23] Gourinchas, Pierre Olivier, Oscar Landerretche, and Rodrigo Valdes (2001), "Lending Booms: Latin America and the World," NBER working paper 8249.

[24] Gupta, Poonam, Deepak Mishra and Ratna Sahay (2001), "Ouput Response to Currency Crises," presented at the 2nd Annual IMF Research conference, 2001

[25] Hallward-Driemeier, Mary (2000), "Firm-Level Survey Provides Data on Asia's Corporate Crisis and Recovery", The World Bank, mimeo.

[26] Helpman, Elhanan (1981), "An Exploration in the Theory of Exchange-Rate Regimes," The Journal of Political Economy, Vol. 89, No. 5, pp. 865-890.

[27] Hutchison, Michael M. and Ilan Neuberger (2002), "How Bad Are Twin Crisis? Output Cost of Currency and Banking Crisis," UCSC International Economics Working Paper 02-1.

[28] Jeanne, O. and J. Zettelmeyer (2001), "International Bailouts, Moral Hazard and Coditionality," Economic Policy, October. 
[29] Kaminski G. and C. Reinhart (1999), "The Twin Crises: The Causes of Banking and Balance of Payments Problems," American Economic Review, 89(3), 473-500.

[30] Kaminsky, Graciela and Sergio Schmukler (2001), "Short-Run Pain, Long-Run Gain: The Effects of Financial Liberalization," mimeo The World Bank.

[31] Krueger, Anne and Aaron Tornell, 1999, "The Role of Bank Lending in Recovering From Crises: Mexico 1995-1998," NBER working paper 7042.

[32] Krugman, Paul (1999), "Balance Sheets, The Transfer Problem, and Financial Crises," mimeo, MIT.

[33] Levy-Yeyati and Sturzenegger (2000), "Classifying Exchange Rate Regimes: Deeds vs. Words," mimeo.

[34] McKinnon, Ronald and Huw Pill (1999), "Exchange-Rate Regimes for Emerging Markets: Moral Hazard and International Overborrowing," Oxford Review of Economic Policy 15(3), Autumn, pages 19-38.

[35] Sachs, Jeffrey, Aaron Tornell and Andres Velasco (1996). "Financial Crises in Emerging Markets: The Lessons From 1995," Brookings Papers on Economic Activity.

[36] Schiffer, Mirjam and Beatrice Weder (2001), "Firm Size and the Business Environment: Worldwide Survey Results," International Finance Corporation Discussion Paper \#43.

[37] Schneider M. and A. Tornell (2000), "Balance Sheet Effects, Bailout Guarantees and Financial Crises," NBER working paper 8060.

[38] Tornell, A (1999), "Common Fundamentals in the Tequila and Asian Crises," NBER working paper 7193. 


\section{Appendix}

\section{Criteria for country selection:}

In the world bank development indicators data base, we consider countries:

a) That have a stock market and the value of the stocks traded as a share of GDP is larger than $1 \%$.

b) That have a population of more than 1 million people.

c) With per capita income of more than $1000 \$$ but less than $18000 \$$

d) That are not engaged in war or civil war (Iran, Irak, Yugoslavia and lebanon)

In addition, we consider Finland and Sweden, who experienced often studied joint currency and banking crisis. In total we have 39 countries. The sample covers 20 years, from 1980 to 1999 . The panel is unbalanced, as not all series cover the full sample or are available for all countries. The data set is available from the authors upon request.

\section{Crisis dates:}

Banking Crisis (BC) and Currency Crisis (CC) dates are taken from Frankel and Rose (1996), Capiro and Klingbiel (1997) and Tornell (1999). A Joint crisis is defined as an event where A) BC and CC occurs in the same year, or consecutive years. B) in consecutive years, the year of the crisis is the year of the latter of the two. C) A joint crisis does not count if it occurs within three year before or after another joint crisis, or when crisis occur three or more years in a row. Out of our sample of 39 countries, 20 have experienced joint crises. The remaining 19 are part of the control group and effect the regression results only via affecting the mean of tranquil times.

\begin{tabular}{|c|c|c|c|c|c|c|c|c|c|c|c|c|c|c|c|}
\hline & $\mathrm{CC}$ & $B C$ & Joint & & $\mathrm{CC}$ & $B C$ & Joint & & $\mathrm{CC}$ & $B C$ & Joint & & $\mathrm{CC}$ & $\mathrm{BC}$ & Joint \\
\hline Argentina * & $\begin{array}{l}82,84, \\
87,89, \\
91,95\end{array}$ & $\begin{array}{l}80,85 \\
89,94\end{array}$ & $\begin{array}{l}85,89, \\
95\end{array}$ & Greece & 83,85 & - & - & Mexico * & $\begin{array}{l}82,85, \\
88,94\end{array}$ & 81,94 & 82,94 & Slovenia & - & - & - \\
\hline Brazil * & $\begin{array}{l}87,90 \\
95,98\end{array}$ & 90,94 & 90,95 & Hungary & - & 91 & - & Morocco * & 81 & 82,95 & 82 & South Africa & $\begin{array}{l}81,82, \\
84,86, \\
88,92, \\
95\end{array}$ & 85 & 85 \\
\hline Chile * & 82,84 & 81 & 82 & $\begin{array}{l}\text { Indonesia } \\
*\end{array}$ & $\begin{array}{l}83,86, \\
97\end{array}$ & 92,97 & 97 & $\begin{array}{l}\text { New } \\
\text { Zealand * }\end{array}$ & $\begin{array}{l}80,84, \\
88\end{array}$ & 87 & 88 & Spain & $\begin{array}{l}82,92, \\
94\end{array}$ & - & - \\
\hline Colombia & - & 82 & - & Ireland & 86,92 & - & - & Peru * & $\begin{array}{l}84,88 \\
90,92\end{array}$ & 83 & 84 & Sweden * & 92 & 91 & 91 \\
\hline Croatia & - & - & - & Israel & - & - & - & Philippines * & $\begin{array}{l}82,83, \\
86,90, \\
97\end{array}$ & 81,97 & 97 & Thailand * & 97 & 83,97 & 97 \\
\hline $\begin{array}{l}\text { Czech } \\
\text { Republic }\end{array}$ & - & - & - & Jordan * & 89 & 89 & 89 & Poland & - & - & - & Tunisia & - & - & - \\
\hline Ecuador * & $\begin{array}{l}82,84, \\
85,88, \\
91,98\end{array}$ & 81,98 & 82,98 & $\begin{array}{l}\text { Korea, } \\
\text { Rep. * }\end{array}$ & 80,97 & 97 & 97 & Portugal & 83 & - & - & Turkey * & $\begin{array}{l}84,91 \\
94,95\end{array}$ & $\begin{array}{l}82,91, \\
94\end{array}$ & 91,94 \\
\hline Egypt * & 89 & 90 & 90 & Latvia & - & - & - & Russia & - & 98 & - & Uruguay * & $\begin{array}{l}82,83, \\
86\end{array}$ & 81 & 82 \\
\hline Estonia & - & - & - & Lithuania & - & - & - & Saudi Arabia & - & - & - & Venezuela * & $\begin{array}{l}86,89, \\
92,94, \\
95\end{array}$ & & 92 \\
\hline Finland * & $\begin{array}{l}86,91, \\
93\end{array}$ & 91 & 91 & Malaysia * & 97 & 85,97 & 97 & \begin{tabular}{|l} 
Slovak \\
Republic
\end{tabular} & - & - & - & & & & \\
\hline
\end{tabular}


Indicators of tadability in Manufacturing and Services:

\begin{tabular}{|c|c|c|c|c|}
\hline & \multicolumn{2}{|c|}{$\begin{array}{l}\text { Standard deviations of the sectoral real } \\
\text { exchange rate }\end{array}$} & \multicolumn{2}{|c|}{ Exports / GDP } \\
\hline & manufacturing & services & manufacturing & services \\
\hline ARG & 0.239 & 0.348 & 0.343 & 0.029 \\
\hline BRA & 0.185 & 0.238 & 0.340 & 0.018 \\
\hline CHL & 0.259 & 0.338 & 1.261 & 0.086 \\
\hline $\mathrm{COL}$ & 0.236 & 0.267 & 0.723 & 0.049 \\
\hline CRO & 0.100 & 0.127 & 1.264 & 0.402 \\
\hline CZE & NA & 0.123 & NA & 0.231 \\
\hline $\mathrm{ECU}$ & 0.156 & 0.342 & 1.080 & 0.075 \\
\hline EGY & 0.416 & 0.458 & 0.614 & 0.245 \\
\hline EST & 0.301 & 0.369 & 2.238 & 0.324 \\
\hline FIN & 0.130 & 0.142 & 1.129 & 0.092 \\
\hline GRC & 0.079 & 0.081 & 0.685 & 0.130 \\
\hline HUN & 0.029 & 0.281 & 1.420 & 0.138 \\
\hline IDN & 0.262 & 0.410 & 1.304 & 0.048 \\
\hline IRL & NA & NA & $\mathrm{NA}$ & 0.127 \\
\hline ISR & NA & NA & NA & NA \\
\hline JOR & 0.225 & 0.307 & 1.774 & 0.438 \\
\hline KOR & 0.138 & 0.148 & 0.967 & 0.089 \\
\hline LTU & 0.571 & 0.652 & 1.892 & 0.161 \\
\hline LVA & 0.542 & 0.478 & 1.283 & 0.268 \\
\hline MEX & 0.148 & 0.264 & 0.855 & 0.040 \\
\hline MOR & 0.141 & 0.242 & 0.950 & 0.122 \\
\hline MYS & 0.149 & 0.207 & 2.639 & 0.200 \\
\hline NZL & 0.145 & 0.163 & 1.126 & 0.092 \\
\hline PER & 0.243 & 0.229 & 0.460 & 0.051 \\
\hline PHL & 0.120 & 0.154 & 0.853 & 0.180 \\
\hline POL & NA & NA & 1.013 & 0.101 \\
\hline PRT & 0.133 & 0.175 & 0.810 & 0.123 \\
\hline RUS & NA & 0.355 & NA & 0.065 \\
\hline SAU & 0.315 & 0.236 & 5.861 & 0.087 \\
\hline SLK & NA & 0.082 & 1.984 & 0.224 \\
\hline SLN & 0.086 & 0.085 & 1.852 & 0.227 \\
\hline SOU & 0.175 & 0.188 & 1.131 & 0.062 \\
\hline SPA & 0.117 & 0.139 & 0.611 & 0.139 \\
\hline SWE & 0.108 & 0.111 & 1.320 & 0.106 \\
\hline THA & 0.088 & 0.170 & 0.992 & 0.140 \\
\hline TUN & 0.223 & 0.204 & 1.652 & 0.219 \\
\hline TUR & 0.134 & 0.127 & 0.656 & 0.113 \\
\hline URU & 0.223 & 0.310 & 0.668 & 0.108 \\
\hline VEN & 0.321 & 0.414 & 1.363 & 0.032 \\
\hline
\end{tabular}

Note: We would expect non-tradables sectors to experience a higher sectoral real exchange rate variance. We consider 3 sectors: construction, services and Manufacturing. We proxy for tradables and non-tradables output in the following way. If there exists construction data, we classify construction as $\mathrm{N}$ by default. We then classify as $\mathrm{T}$ the sector that exhibits the least variable sectoral real exchange rate. If construction data are not available, we classify as non-tradable the sector with the least variable exchange rate. The table presents information that helps to classify Manufacturing as $\mathrm{N}$ or $\mathrm{T}$. 
Figure A: The boom bust cycle under fixed and non-fixed exchange rate regimes (de jure classification)

\section{Fixed}

Real Appreciation

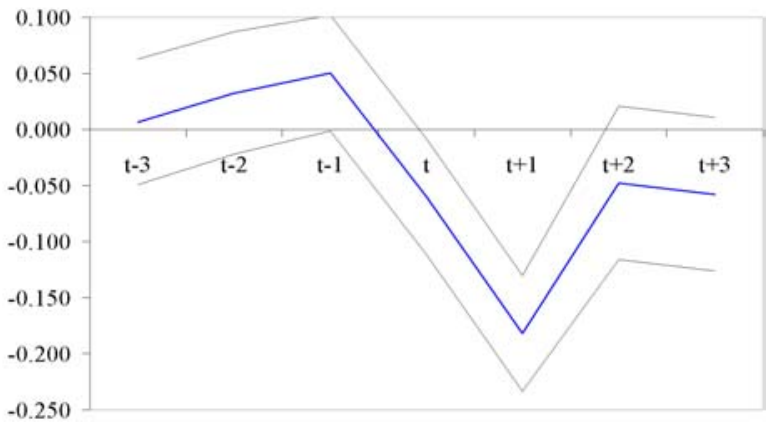

Aggregate output

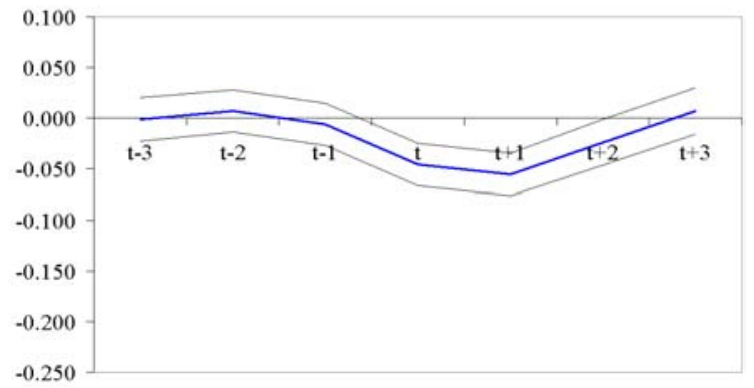

Credit/Deposits

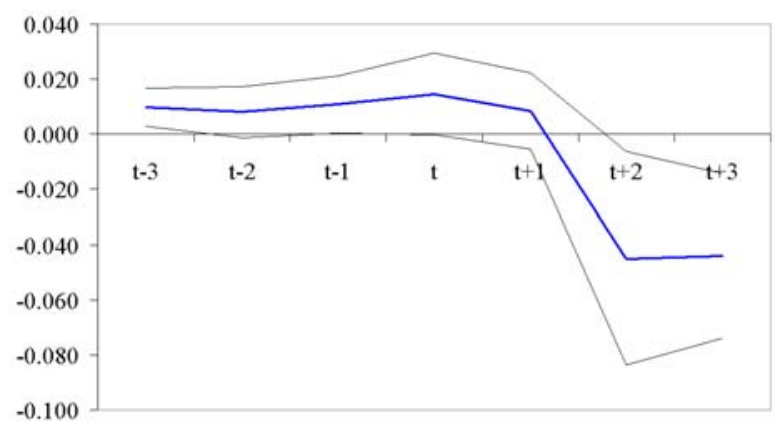

Non-tradables-to-Tradables Output Ratio

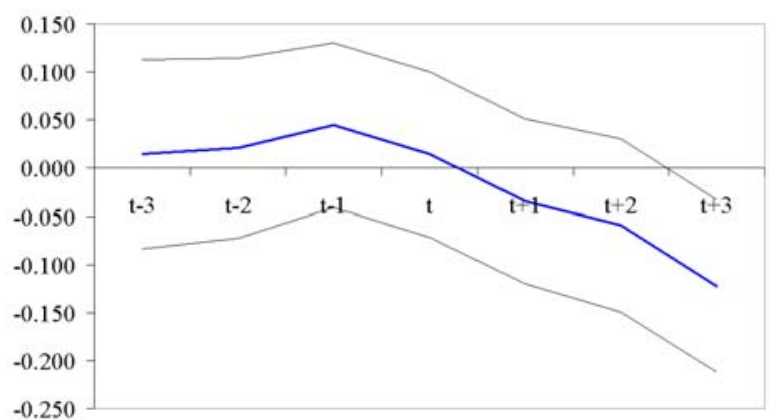

Non-Fixed
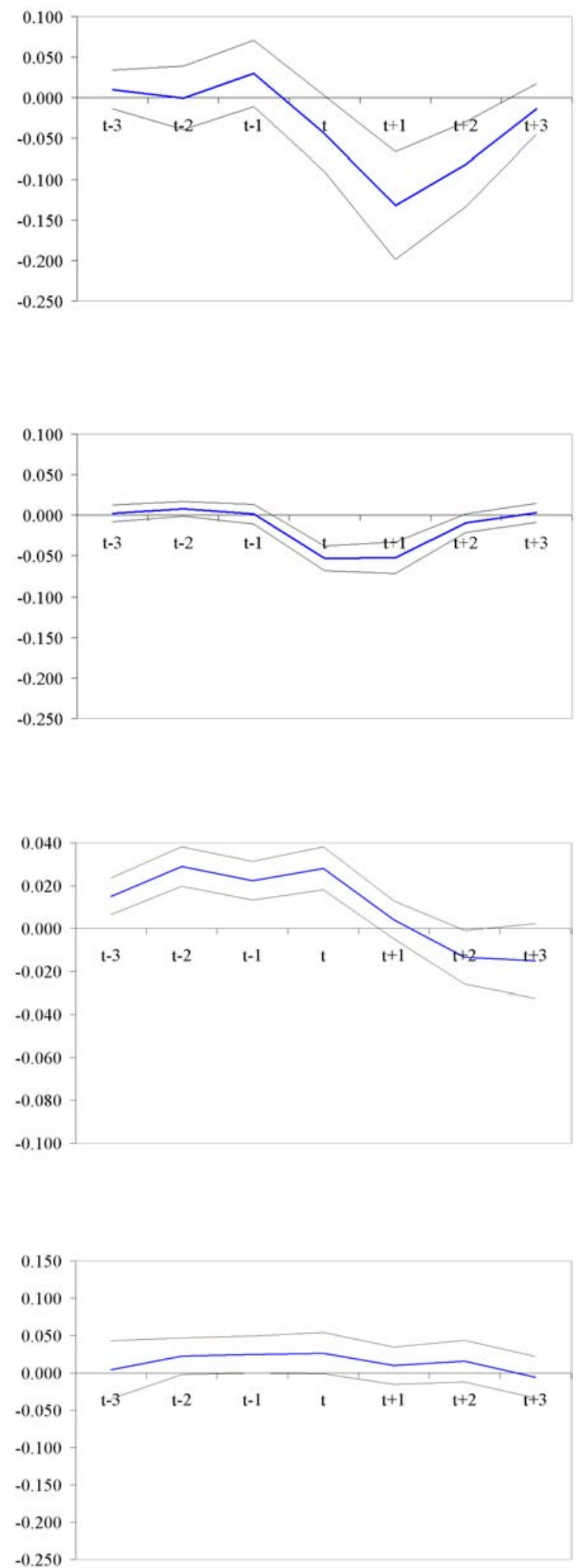


\section{Figure A: Continued}

Investment/GDP
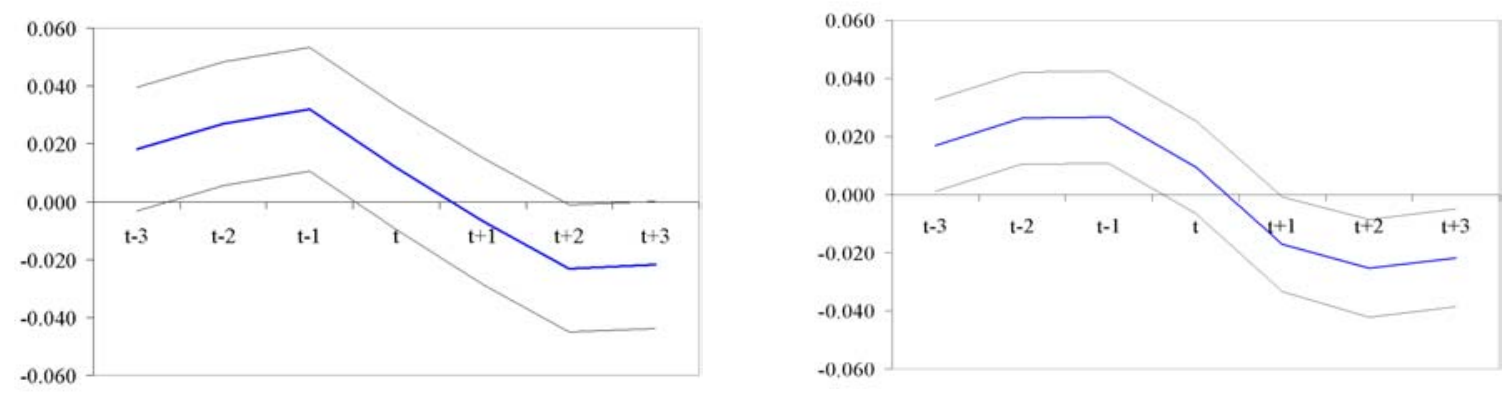

\section{Consumption/GDP}
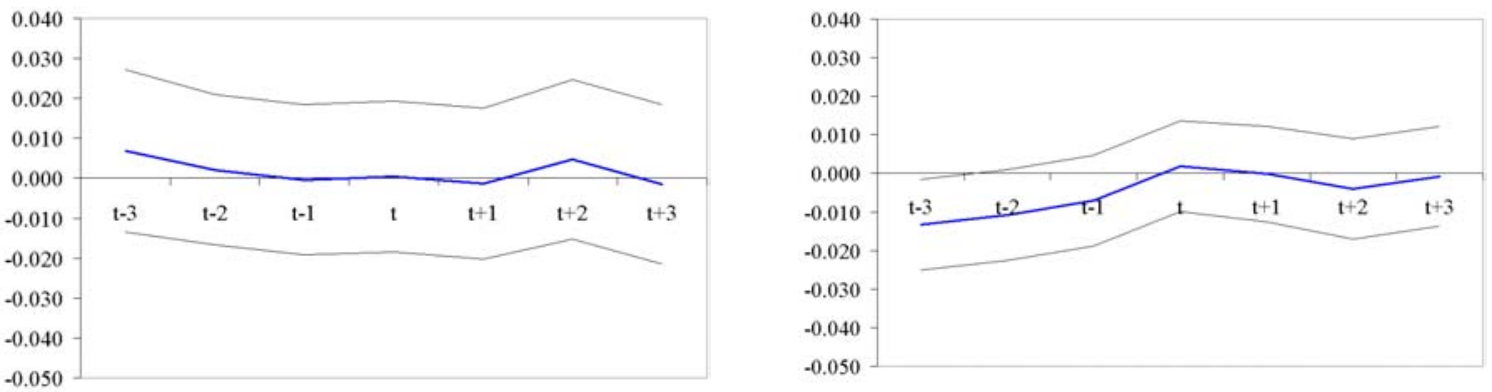

Note: Fixed and non-fixed regimes are determined according to the de Jure classification by Berger et. al (2001). For the construction of the event windows see footnote to figure 1 . 
Figure B: the boom bust cycle in 11 frequently studied countries:

Argentina, Brazil, Chile, Indonesia, Finland, Korea, Malaysia, Mexico, Philippines, Sweden, Thailand

\section{1/ Real Exchange Rate (growth rates)}

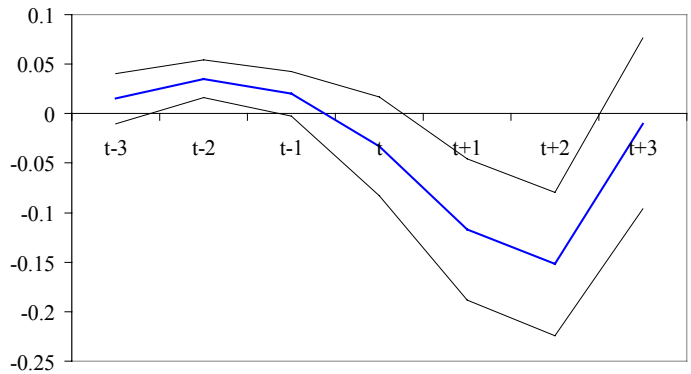

Real GDP (growth rates)

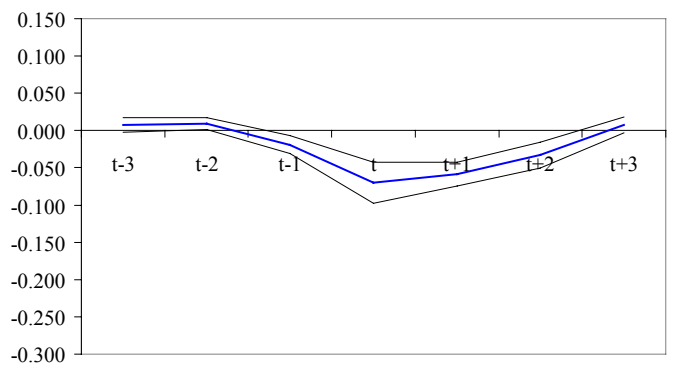

Real credit (growth rates)

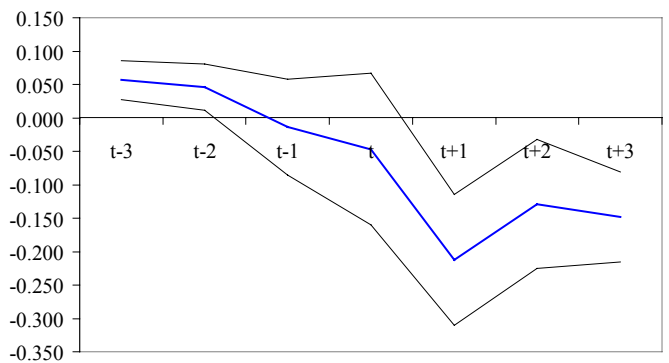

\section{Credit/GDP (levels)}

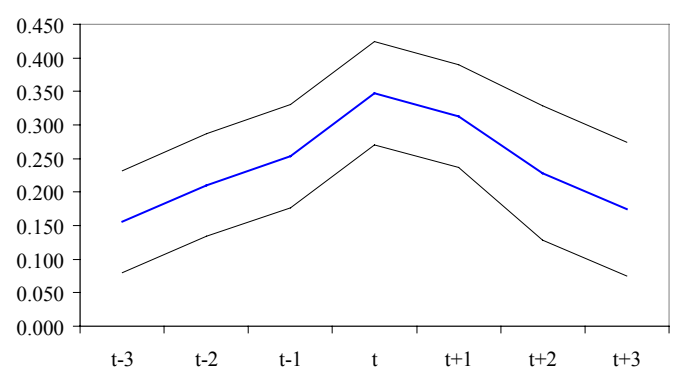

Real GDP - deviations from HP-Trend

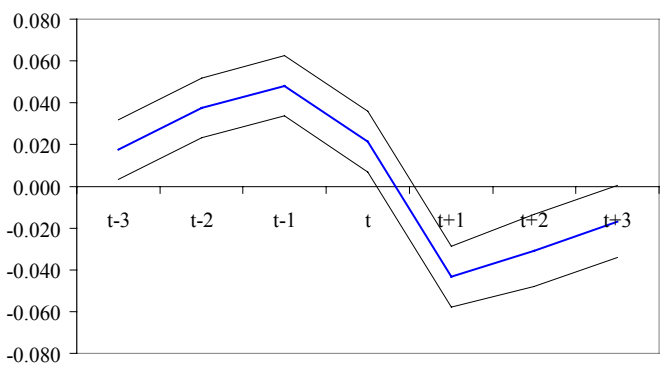

Real Credit - dev. from HP-Trend

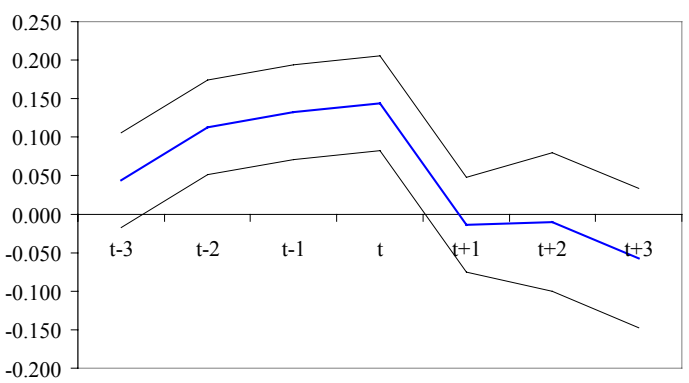

Credit/Deposits (levels)

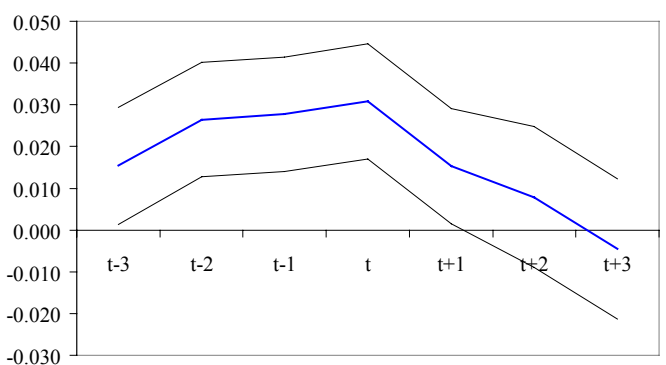


Figure B: continued

N/T (Levels)

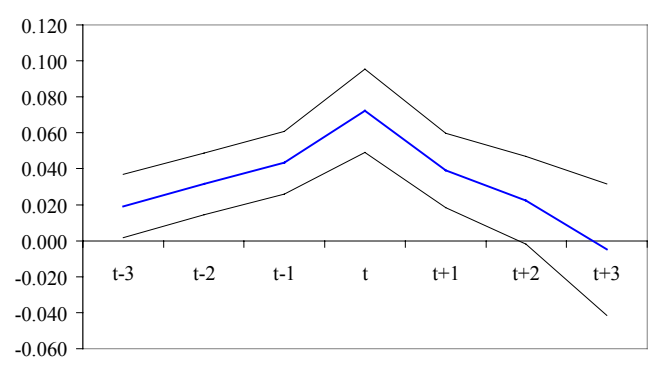

Interest rate spread (levels)

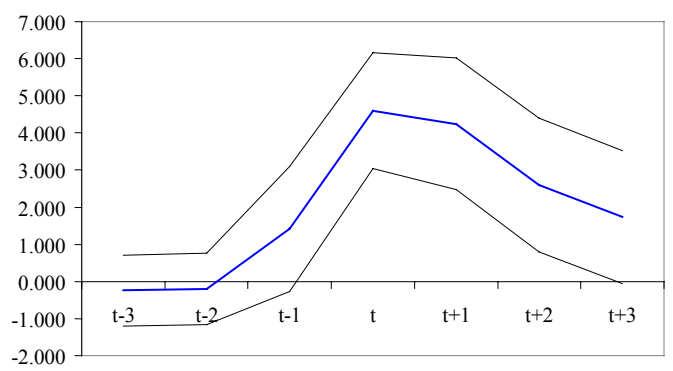

\section{Investment/GDP (levels)}

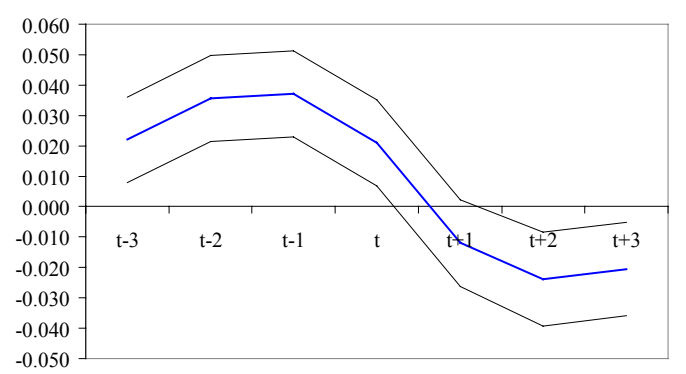

Terms of Trade

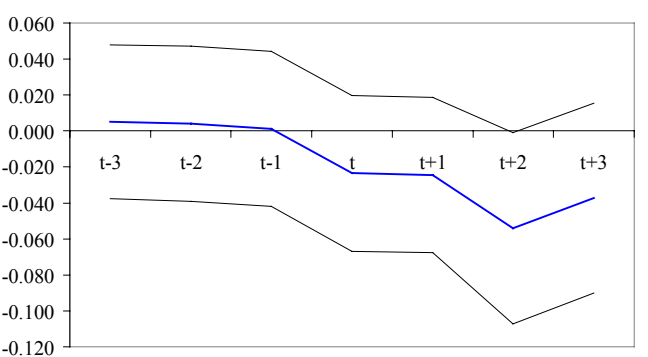

Real interest rates (levels)

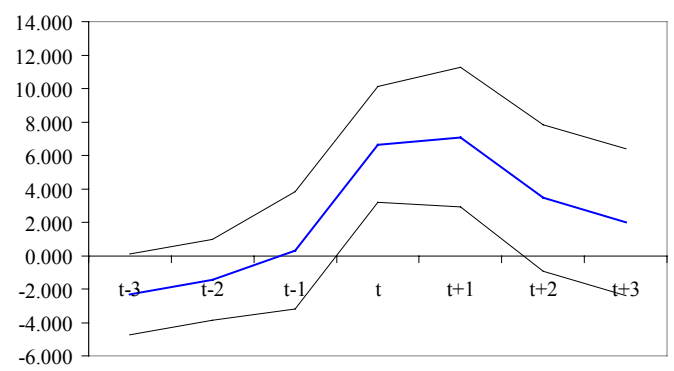

Consumption/GDP (levels)

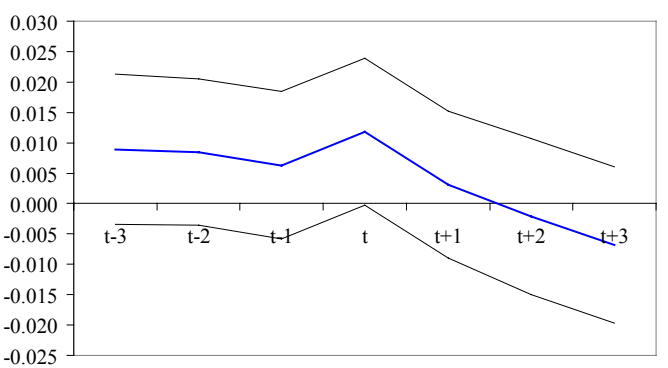




\section{Data sources:}

Real exchange rate: IMF, International financial Statistics, CD-ROM. (Lines ..RECZF)

Real GDP growth rates: World Bank Development indicators (Code: NY.GDP.MKTP.KN)

Real credit growth: IMF, International financial Statistics, CD-ROM. Claims on private sector by deposit money banks (Lines 22d..ZF), divided by CPI (Lines 64..ZF)

Deposits: IMF, International financial Statistics, CD-ROM. (Demand deposits, Lines 24..ZF + Time, savings and foreign currency deposits, Lines 25..ZF)

N/T: Services: World Bank Development indicators (Code: NV.SRV.TETC.KN), Manufacturing: World Bank Development indicators (Code: NV.IND.MANF.KN), Construction: OECD Statistical Compendium, Main indicators of industrial activity and individual central banks.

Interest rate spread: World Bank Development indicators (Code: FR.INR.LNDP)

Real interest rate: World Bank Development indicators (Code: FR.INR.RINR)

Gross domestic fixed investment: World Bank Development indicators (Code: NE.GDI.FTOT.KN)

Private Consumption: World Bank Development indicators (Code: NE.CON.PRVT.KN)

Dates of financial liberalization: see Baekert et.al (2001). 